City University of New York (CUNY)

CUNY Academic Works

$9-2018$

\title{
The Impact of Defendant Gender and Attractiveness on Juror Decision-Making in a Sexual Offense Case
}

Georgia M. Winters

The Graduate Center, City University of New York

\section{How does access to this work benefit you? Let us know!}

More information about this work at: https://academicworks.cuny.edu/gc_etds/2855

Discover additional works at: https://academicworks.cuny.edu

This work is made publicly available by the City University of New York (CUNY).

Contact: AcademicWorks@cuny.edu 


\section{THE IMPACT OF DEFENDANT GENDER AND ATTRACTIVENESS ON JUROR DECISION-MAKING IN A SEXUAL OFFENSE CASE}

by

GEORGIA M. WINTERS

A dissertation submitted to the Graduate Faculty in Clinical Psychology in partial fulfillment of the requirements for the degree of Doctor of Philosophy, The City University of New York 
(C) 2018

\section{GEORGIA M. WINTERS}

All Rights Reserved 
The Impact of Defendant Gender and Attractiveness on Juror Decision-Making in a Sexual

$$
\text { Offense Case }
$$

by

Georgia M. Winters

A dissertation submitted to the Graduate Faculty in Clinical Psychology in partial fulfillment of the requirements for the degree of Doctor of Philosophy, The City University of New York

Date

Date
Elizabeth Jeglic

Chair of Examining Committee

Richard Bodnar

Executive Officer

Supervisory Committee:

Cynthia Calkins, Ph.D.

Michele Galietta, Ph.D.

Bonnie Klentz, Ph.D.

Brandy Blasko, Ph.D. 


\begin{abstract}
The Impact of Defendant Gender and Attractiveness on Juror Decision-Making in a Sexual Offense Case

by
\end{abstract}

Georgia M. Winters

Advisor: Elizabeth Jeglic, Ph.D.

In recent years, instances of educator sexual assault against students have flooded the media. In particular, female teachers who abused students have seized the public's attention as they are often portrayed as attractive and a sexual fantasy. This portrayal can then impact the way society perceives these sexual assaults. Importantly, however, it is not known whether this perception influences the prosecution and sentencing of these cases. The current study examined the impact of gender and attractiveness of a teacher, as well as gender of the student victim, on juror decision-making in a teacher/student sexual assault case. Using a 2 (Teacher Gender) X 2 (Student Gender) X 3 (Attractiveness Level: Attractive/Unattractive/No Photo) experimental design, we examined jurors' decisions regarding guilt, sentencing, and perceptions of the teacher and student. Results suggest that the gender of the teacher may impact juror decision-making; however, the level of attractiveness of the teacher and gender of the student had minimal effects. The study contributes to our understanding of how educators who commit sexual acts against students are perceived and treated in the court system and what variables may impact those perceptions. Overall, the present study has important theoretical and practical implications for criminal justice professionals, treatment providers, and the community at large.

Keywords: sexual assault, teacher sexual assault, juror decision-making 


\section{ACKNOWLEDGMENTS}

A special thank you to Dr. Elizabeth Jeglic for her unwavering support and guidance throughout my years in the doctoral program. Her mentorship has truly been invaluable in all of my research, clinical, and teaching endeavors. In addition, thank you to my dissertation committee members, Drs. Cynthia Calkins, Michele Galietta, Bonnie Klentz, and Brandy Blasko, as their contributions were instrumental in this process. Lastly, thank you to my family and friends who provided immeasurable support along the way. 


\section{TABLE OF CONTENTS}

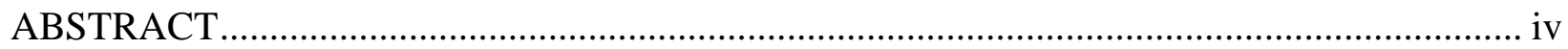

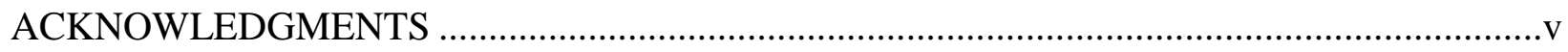

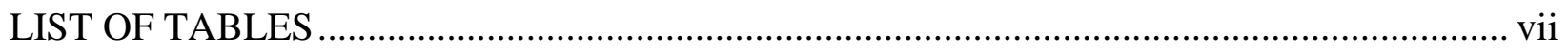

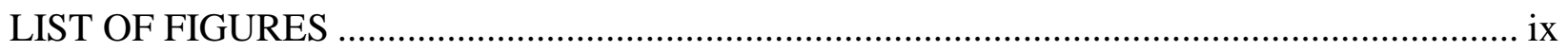

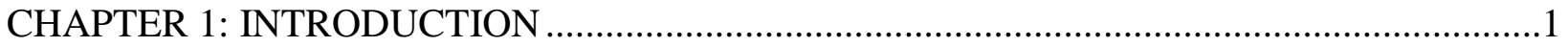

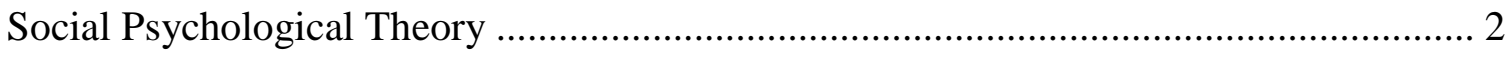

The Impact of Physical Attractiveness on Juror Decision-Making ............................... 4

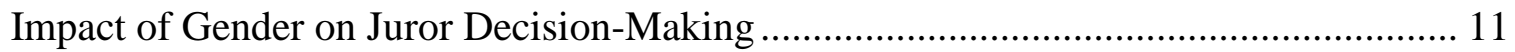

Teacher and Student Sexual Abuse Cases ............................................................. 13

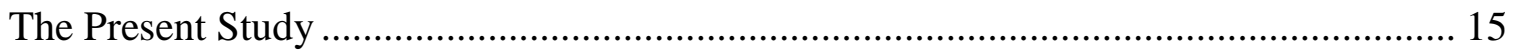

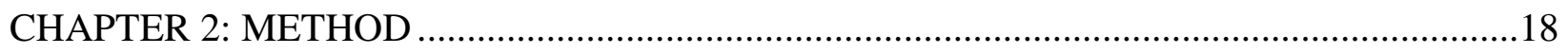

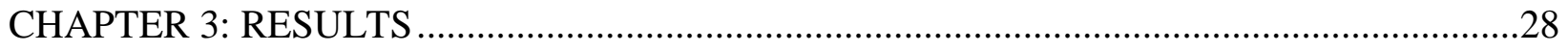

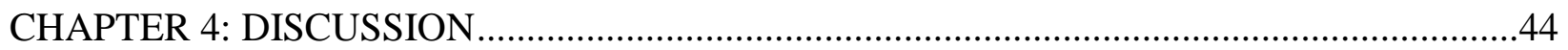

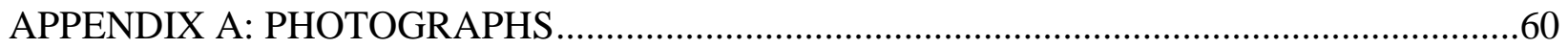

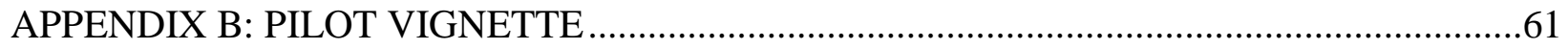

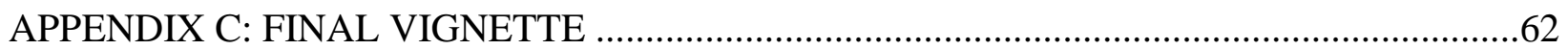

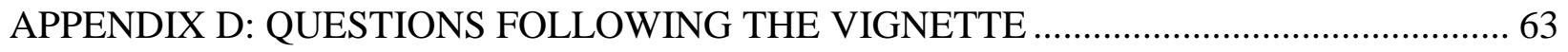

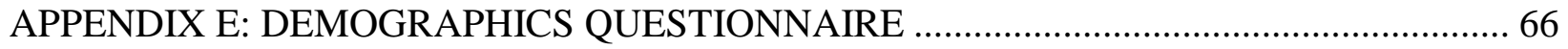

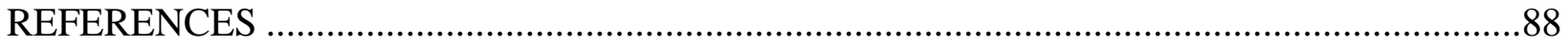




\section{LIST OF TABLES}

Table 1. Mean guilt ratings as a function of Attractiveness Level and Teacher Gender

Table 2. Binomial Logistic Regression Predicting Likelihood of a Guilty Verdict based on

Attractiveness Level, Teacher Gender, Student Gender, and Participant Gender

Table 3. Extent of Guilt Ratings as a Function of Attractiveness Level, Teacher Gender, and

Student Gender.

Table 4. Extent of Guilt Ratings as a Function of Attractiveness Level, Teacher Gender, and

Participant Gender

Table 5. Confidence Ratings as a Function of Attractiveness Level, Teacher Gender, and Student

Gender.

Table 6. Sex Offense was Committed Ratings as a Function of Attractiveness Level, Teacher

Gender, and Student Gender.....

Table 7. Likelihood of Reoffending Ratings as a Function of Attractiveness Level, Teacher

Gender, and Student Gender.

Table 8. Sex Offender Registration Ratings as a Function of Attractiveness Level, Teacher

Gender, and Student Gender.

Table 9. Sex Offender Treatment Ratings as a Function of Attractiveness Level, Teacher Gender, and Student Gender. .76

Table 10. Community Notification Ratings as a Function of Attractiveness Level, Teacher

Gender, and Student Gender.

Table 11. Teacher Responsibility Ratings as a Function of Attractiveness Level, Teacher Gender,

and Student Gender. .78 
Table 12. Teacher Credibility Ratings as a Function of Attractiveness Level, Teacher Gender,

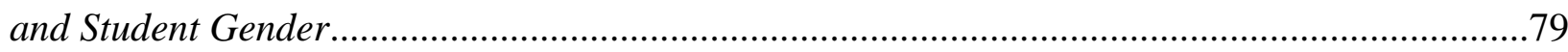

Table 13. Teacher Empathy Ratings as a Function of Attractiveness Level, Teacher Gender, and

Student Gender.

Table 14. Student Blameworthiness Ratings as a Function of Attractiveness Level, Teacher

Gender, and Student Gender.....

Table 15. Student Responsibility Ratings as a Function of Attractiveness Level, Teacher Gender, and Student Gender.

Table 16. Student Credibility Ratings as a Function of Attractiveness Level, Teacher Gender, and Student Gender.

Table 17. Student Empathy Ratings as a Function of Attractiveness Level, Teacher Gender, and Student Gender. 


\section{LIST OF FIGURES}

Figure 1. Mean teacher responsibility ratings as a function of teacher gender and student gender

Figure 2. Mean teacher credibility ratings as afFunction of teacher gender and attractiveness

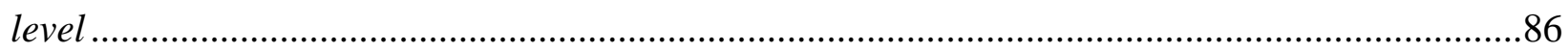

Figure 3. Mean student empathy ratings as a function of teacher gender and student gender .....87 


\section{CHAPTER 1}

\section{INTRODUCTION}

In 1997, the nation was shocked by the arrest of Mary Kay Letourneau, a Washington State teacher, for having sexual relations with her 12-year-old male student. She pled guilty to two counts of second degree rape of a child and was sentenced to six months in jail (three months suspended), with a stipulation of no contact with her victim (Stennis, 2006). Letourneau was not mandated to register as a sex offender at that time, which was typically required of individuals who were found guilty of sexual offenses. Additionally, in Washington, the initial crime she was originally convicted of is typically punished by an indeterminate sentence of 5 years to life in prison (Norman-Eady, Reinhart, \& Martino, 2003). Once released, she violated the no-contact order with the victim, and only then was she was re-sentenced to a more severe prison term of seven years. Since this case, there have been numerous other instances in the media of female teachers receiving minimal jail or probation sentences for sexual offenses against students, which sharply juxtapose the typical 3 to 13 year prison sentence recommendations for these types of sexual assault cases (Cairns, 2012). This raises the question as to why female perpetrators are seemingly receiving more lenient treatment in the criminal justice system than the typical sexual offense guidelines.

As in the case of Mary Kay Letourneau, female teachers who sexually offend against male students are often portrayed as young, physically attractive women (Larosa, 2014). These types of incidents with female teachers have been popularly portrayed as a young man's fantasy, with many viewing these young boys as lucky to have had a sexual experience with an attractive, older female. These societal depictions of attractive teachers can be seen throughout the media, such as Internet websites (e.g., 50 Hot Teachers That Slept With Their Students, 2016), movies 
(e.g., "Notes on a Scandal”, “A Teacher"; Block, 2017), music (e.g., "Hot for Teacher” by Van Halen; Simcha, 2008), and other cultural fads (e.g., "sexy school teacher" costumes; pornography featuring student/teacher sexual relations). While society often portrays sex with a female teacher as a sexual fantasy, on the contrary, male victims of sexual assault are likely to experience an array of negative outcomes (e.g., psychological and behavioral problems; Davies \& Rogers, 2006; Mezey \& King, 1989; Walker, Archer, \& Davies, 2005). In 2014, there were 781 media reports of student/teacher sexual assaults in that year alone, with $32 \%$ of the stories covering female perpetrators (Abbott, 2015). As instances of statutory rape committed by female teachers flood the news, there is much need for research examining how this type of offender is viewed in the criminal justice system. To this end, the present study will seek to examine the impact of physical attractiveness and gender of a defendant on juror decision-making in a student/teacher sexual assault case.

\section{Social Psychological Theory}

Research has long supported a Halo Effect, which posits that one positive trait or characteristic influences or extends to other qualities of an individual (Nisbett \& Wilson, 1977). The Halo Effect biases a person's perceptions and judgments by focusing on only the good qualities of the person. The term was originally coined by Edward Thorndike in 1920 after he found that when commanding officers were asked to evaluate soldiers, the ratings for various qualities (i.e., physical appearance, leadership skills, intelligence, personal attributes) were highly correlated with one another. He concluded that a "halo of general merit" extends to influence a person's judgment of other qualifications and skills. A study conducted by Nisbett and Wilson (1997) further supported his notion. They found that when undergraduates were asked to evaluate a college instructor who was either warm/friendly or cold/distant, the 
participants rated the warm instructor more favorably on a variety of factors (e.g., physical appearance, mannerisms, voice). Since these pioneering studies, there has been a wide body of literature that has explored the influence of one trait in particular, physical attractiveness, on subsequent judgments of the individual.

The What is Beautiful is Good stereotype suggests that physically attractive people are perceived as superior to unattractive people in a variety of domains (Dion, Bersheid, \& Walster, 1972). Research has indeed revealed that physical attractiveness and likability exhibit a linear relationship (Stroebe, Insko, Thompson, \& Layton, 1971), in that as levels of attractiveness increase, levels of likability increase as well. For example, attractive individuals are seen as more sociable, smart, popular, kind, and well-adjusted (Eagly, Ashmore, Makhijani, \& Longo, 1991; Langlois, et al., 2000). Attractive people are perceived to have more socially desirable personalities and lead happier, more productive lives compared to unattractive people. Other studies have shown that physically attractive individuals are viewed as having more favorable traits and behaviors compared to their unattractive counterparts, such as higher quality performances on tasks (Landy \& Sigall, 1974), more persuasive (Mills \& Aronson, 1965), and more marketability on the job market (Dipboye, Fromkin, \& Wiback, 1975). The What is Beautiful is Good stereotype has been found to be quite pervasive, as it has been demonstrated across various age groups and situations (Byrne, London, \& Reeves, 1968).

It has been proposed that the What is Beautiful is Good stereotype may develop from two sources: 1) direct observation; and 2) societal portrayals (Eagly et al., 1991). Direct observation refers to people observing that attractive individuals are well-liked by peers and treated more favorably by everyone around them. Further, it has been suggested that society portrays physically attractive people in movies, advertisements, and children's stories as being rich, 
successful, and happy. Taken together, a person may learn that What is Beautiful is Good through these personal observations and societal portrayals.

As noted above, attractive people are often viewed in a more favorable light as a result of the Halo Effect and What is Beautiful is Good stereotype. Given the pervasiveness of the What is Beautiful is Good stereotype, researchers have been interested in the impact of this phenomenon on decision-making in the criminal justice system, suggesting that there is a potential Attractiveness Leniency Bias (e.g., Abel \& Watters, 2005; Stewart, 1980; 1985). As the name suggests, the bias posits that physically attractive individuals will be treated more leniently in regards to the guilt and sentencing decisions of jurors. Empirical research has supported this notion for minor transgressions, demonstrating that attractive individuals are deemed less responsible compared to their unattractive counterparts. Efran (1974) found that attractive male and female students were viewed as less guilty and received less severe punishments when accused of cheating on an exam compared to the unattractive students. While Efran's study depicted a minor indiscretion (i.e., cheating on an exam), the findings raise the question as to whether physical appearance may influence more severe misconduct, such as those found in the criminal justice context. Given the high stakes for a defendant at trial, it is vital to understand how the appearance of a defendant may influence the decisions made by a jury.

\section{The Impact of Physical Attractiveness on Juror Decision-Making}

While the purpose of a juror is to evaluate the legal evidence, often extralegal factors have an influence on a juror's judgments of guilt and sentencing (Erian, Lin, Patel, Neal, \& Geiselman, 1998). These extralegal factors can be conceptualized into three categories: 1) juror characteristics (e.g., gender, beliefs); 2) procedural characteristics at trial (e.g., jury instructions); and 3) defendant characteristics (e.g., race, gender, socioeconomic status; Izzett \& Leginski, 
1974). The present study namely focuses on the latter, with emphasis on the extralegal factors of defendant physical attractiveness. While the defendant's level of attractiveness should be irrelevant to guilt or sentencing in a case, the Halo Effect, What is Beautiful is Good stereotype, and Attractiveness Leniency Bias would suggest otherwise.

\section{Guilt Determinations}

There is some evidence that jurors are more likely to acquit attractive defendants and convict unattractive defendants (e.g., Abwender \& Hough, 2001; Kerr, 1978; Kulka \& Kessler, 1978; Wilson \& Donnerstein, 1977). This has predominantly been found for empirical studies that use cases involving rape (e.g., Deitz \& Byrnes, 1981) and sexual harassment (e.g., Castellow, Wuensch, \& Moore, 1990). One study found that female participants rated the unattractive female defendant as more guilty compared to the attractive female defendant in a vehicular homicide case (Abwender \& Hough, 2001), though male participants showed the opposite pattern. Thus, the attractiveness leniency bias was found for guilt ratings in this case, but only for female jurors.

Notably, other studies of sexual assault did not show any impact of defendant attractiveness on guilty verdicts (e.g., Austin, Plumm, Terrance, \& Terrell, 2013; Erian et al., 1998). The effect has also not been replicated for other types of crimes, such as domestic violence (e.g., Burke, Ames, Etherington, \& Pietsch, 1990), homicide (e.g., Sigal, Braden, \& Aylward, 1978), or robbery (e.g., Sigal et al., 1978). Lastly, evidence from field studies has not supported an Attractiveness Leniency Bias, in that the defendant's physical attractiveness had no impact on conviction rates in real-world court scenarios (Stewart, 1980; 1985). Taken altogether, it appears that the impact of appearance of defendant on acquittal and conviction rates may be limited to cases involving sexually inappropriate behaviors and vehicular homicide. 


\section{Sentencing Decisions}

Similar to the varied findings on the impact the Attractiveness Leniency Bias has on verdicts, there are also inconsistent results for sentencing decisions. Some studies have revealed an apparent Attractiveness Leniency Bias for punishment determinations (e.g., Friend \& Vinson, 1974; Gerdes, Dammann, \& Heilig, 1988; Gray \& Ashmore, 1976; Izzett \& Fishman, 1976; Izzett \& Leginski, 1974; Leventhal \& Krate, 1977; Piehl, 1977; Smith \& Hed, 1979; Stewart, 1985; Thornton, 1977). For example, attractive defendants have been assigned lesser sentences in rape and sexual assault cases (e.g., Erian et al., 1998; Jacobson, 1981; Jacobson \& Popovich, 1983), negligent homicide (e.g., Nemeth \& Sosis, 1973), and white collar crimes (e.g., Solomon, \& Schoplerl, 1978). Field studies examining actual courtroom data have supported the link between increased attractiveness and decreased sentence lengths in sentences ascribed by judges (Stewart, 1980; 1985). Abwender and Hough (2001) found that female participants ascribed more lenient sentences to the attractive female defendant, while males recommended longer sentences for the attractive female.

Importantly, the Attractiveness Leniency Bias's effect on sentencing has not been universal across studies. Other studies have not shown an effect for certain types of crimes, such as negligent homicide (e.g., Jacobson and Berger, 1974), sexual assault (e.g., Austin et al., 2013), and swindling (e.g., Shechory-Bitton \& Zvi, 2015; Sigall \& Ostrove, 1975). Taken together, while there are some inconsistencies in the body of literature, there appears to be stronger evidence for the Attractiveness Leniency Bias in sentencing compared to guilt determinations.

\section{Meta-analytic Evidence}

A meta-analysis by Mazzella and Feingold (1994) examined the impact of the physical attractiveness of the defendant on guilt and sentencing decisions. First, the meta-analysis 
uncovered that physically attractive defendants were found less guilty compared to unattractive defendants $(d=.19)$ and that jurors ascribed less punishment for more attractive defendants compared to less attractive ones $(d=.21)$. The authors suggest that jurors treat attractive defendants more leniently because they are perceived as more likeable, which leads to lower levels of conviction and punishment. Overall, based on meta-analytic evidence, there appears there is an overall finding for physical appearance on juror judgments, albeit small in effect size.

\section{Sexual Offense Cases}

Of particular interest to the present study, some studies have explored the impact of attractiveness in cases of sexual offenses, including teacher/student sexual assault. There appears to be evidence for an Attractiveness Leniency Bias on guilt determinations for rape (Deitz \& Byrnes, 1981), as well as for sentencing decisions in rape and sexual assault cases (Erian et al., 1998; Jacobson, 1981; Jacobson \& Popovich, 1983). In a study of student/teacher sexual assault, attractiveness of the defendant impacted conviction but only when participants were uncertain whether a crime had actually occurred (Austin et al., 2013). The effect has also been demonstrated in civil cases, with attractiveness of both a defendant and plaintiff having an impact on convictions in a sexual harassment case (Castellow et al., 1990). However, these findings are not universal, with other research finding negligible effects of an Attractiveness Leniency Bias (e.g., Ahola, Christianson, \& Hellstrom, 2009).

\section{Factors Impacting the Varied Findings}

Given the varied findings related to the impact of attractiveness, it is helpful to examine specific variables that may be influencing these findings. Of relevance to the present study, participant gender, type of crime, and the manipulation of attractiveness may be factors related to the varied findings. 
Participant gender. While some studies have shown both male and female participants rate an attractive defendant as less guilty and requiring of less punishment (e.g., Efran, 1974), there have also been studies that suggest differential effects of the Attractiveness Leniency Bias based on the mock jurors' gender. There are a handful of studies that have shown the Attractiveness Leniency Bias solely affects female participants, which was found in cases of negligent homicide (Abwender \& Hough, 2001) and swindling (Wuensch, Castellow, \& Moore, 1991). Alternatively, another cluster of studies have shown the Attractiveness Leniency Bias impacts only male participants. Studies on mock juror decision-making in rape cases have found that males were more lenient to attractive female defendants, whereas female participants did not show this pattern (e.g., Thornton, 1977). There are several explanations for this finding. First, it may be that females overall have a greater understanding of sexual assault and more empathy to the victim, leading to equal treatment of a defendant regardless of attractiveness. Second, it has been proposed the Attractiveness Leniency Bias may only be in effect when rating a defendant of the opposite gender, because attractiveness would be more salient (Abwender \& Hough, 2001). It is important to note that many studies unfortunately did not test for participant gender effects (e.g., Friend \& Vinson, 1974; Jacobson \& Berger, 1974; Kulka \& Kessler, 1978; Smith \& Hed, 1979; Solomon \& Schoplerl, 1978). It is possible that these analyses could have shed light on the inconsistencies described above. Accordingly, there is a need for more evidence regarding participant gender effects when exploring the Attractiveness Leniency Bias.

Type of crime. It has long been suggested that the type of case stimuli in experimental studies may impact whether an Attractiveness Leniency Bias was found. Sigall and Ostrove (1975) conducted the pioneering study showing that attractiveness may not influence decisionmaking for a female defendant who committed certain types of crimes. Using a swindling or a 
burglary case, the results showed that participants were more lenient to the attractive defendant in the burglary case, but treated her more harshly in the swindling case. The authors suggest that harsher punishments were ascribed in the swindling case because the defendant was perceived to have used her attractiveness to her advantage, so her appearance became a liability in this instance. This so called "boomerang effect" was replicated by Smith and Hed (1979) for the same two crimes and has also been found in several other studies (e.g., Boor, 1976; Wuensch, Chia, Castellow, Chuang, \& Cheng, 1993).

In their meta-analysis, Mazella and Feingold (1994) found that the impact of attractiveness on punishment decisions differed significantly by type of crime. Specifically, they found physically attractive defendants were ascribed less punishment in instances of robbery, rape, and cheating on an exam. However, attractive defendants were given more severe punishment in negligent homicide cases and equal punishment in swindling cases. In sum, there is some evidence that the impact that defendant attractiveness has on sentencing may be mediated by the type of criminal case presented to participants. Specifically, there appears to be evidence that cases of sexual assault may be subject to the Attractiveness Leniency Bias, and thus is in need of further examination.

Attractiveness manipulation. The way in which physical attractiveness is manipulated may also help explain some of the inconsistencies in findings. For example, studies vary based on whether attractiveness was manipulated by providing a written or verbal description of the defendants (e.g., Abwender \& Hough, 2001; Nemeth \& Sosis, 1973) while others provide a photograph (e.g., Darby \& Jeffers, 1988; Erian et al., 1988). It may be that jurors respond differently to verbal descriptions of physical attractiveness compared to the more salient visual images. Sigal and colleagues (1978) suggested that photographs may provide a more realistic 
representation of defendant appearance compared to written descriptions, which might lead a juror to recognize they should be objective and avoid biased decision-making.

Even amongst the studies that utilize photographs, there are potential issues in the stimuli. There are questions as to whether the manipulation of attractiveness in photographs is accurately targeting the construct of physical attractiveness. For example, Jacobson and Berger (1974) manipulated how neatly the defendant appeared as a means of defining attractiveness (i.e., disheveled clothes versus clean clothing). Similarly, Sigal and colleagues (1978) selected an attractive photo through pilot testing, then used the photo to create a sloppily dressed person and altered the makeup, lighting, and facial expression to develop the unattractive photograph. In another study, Abel and Watters (2005) conflated smiling with physical attractiveness in their results based on the fact that participants rated the smiling defendant as more physically attractive than a non-smiling one. However, drawing conclusions about physical attractiveness from these results should be made cautiously.

Another point of contention involves the common use of yearbook photographs as stimuli (e.g., Darby \& Jeffers, 1988; Erian et al., 1998), given these photographs typically feature a young adult and may display overall positive facial expressions. Other studies note that the photographs used were black and white, which is not particularly applicable to a real-world juror viewing a defendant in person. Lastly, some studies described photograph attractiveness ratings that do not fully grasp each end of the spectrum (i.e., attractive and unattractive). For example, Austin and colleague's (2013) “unattractive" female photograph was rated 2.94 on a scale of not at all attractive (1) to very attractive (5), a rating which arguably would represent an "average" level of attractiveness. 
For the reasons outlined above, results from Attractiveness Leniency Bias studies may vary based on how attractiveness was manipulated. Jurors may respond differently to written descriptions of physical attractiveness compared to visual representations in the form of photographs. In studies that use photographs, there are questions as to how physical attractiveness was manipulated. Therefore, the present study aims to utilize more realistic stimuli (i.e., colored photographs of actual adult defendants) in order to better represent the construct of attractiveness, as well as control for other facial features (i.e., facial expression, perceived age).

\section{Impact of Gender on Juror Decision-Making}

While attractiveness has the potential to impact juror decision-making, it is also important to examine other extralegal factors such as gender of the defendant, victim, and juror.

\section{Gender of the Defendant}

Some studies have supported the finding that gender of the defendant (independent of attractiveness) has an impact on decision-making. Cramer (1999) concluded that female offenders are less likely to be found guilty than male offenders in domestic violence cases, which has also been shown to hold true in the case of child sexual abuse (Fallman \& Christianson, 1999). However, meta-analytic evidence has not shown the gender of the defendant to be related to guilt ratings (Mazzell \& Feingold, 1994), though there was a small effect size for the impact of gender on sentencing. That is, female defendants tended to receive lower punishment compared to male defendants, though this effect was mostly attributable to studies showing leniency toward females when the crime was theft. More recent studies have shown that females typically received 'substantially shorter' sentences than their male counterparts for violent crimes (Rodriguez, Curry, \& Lee, 2006). In regards to child sexual assault cases, there is evidence that a female perpetrator is treated more leniently compared to a male offender, which 
was especially true for male jurors and when the victim is male (Quas, Bottoms, Haegerich, \& Nysse-Carris, 2002). Of particular importance to the present study, there is some evidence that male defendants were treated more harshly compared to female defendants in a student/teacher sexual assault case, when the situation was perceived as initiated by the teacher (Howell, Egan, Giuliano, \& Ackley, 2011). Pozzulo, Dempsey, Maeder, and Allen (2010) also found that jurors provided higher guilt ratings for a male versus female defendant in a student/teacher sexual assault case. Taken together, there is some research showing that gender of the defendant has an effect on guilt and sentencing. Specifically, being female may lead to lower guilt and sentencing ratings, particularly in the case of sexual offenses.

\section{Gender of the Victim}

The body of literature examining how gender of the victim can impact juror decisions in sexual assault cases is largely mixed and interacts with other variables, such as defendant and participant gender. One study revealed that individuals are more likely to believe a female child victim's report compared to a male child's claim (Haegerich \& Bottoms, 2000). Another study using a child sexual assault case found differences in the impact victim gender has on male and female participants (Quas et al., 2002). Female participant judgments were minimally impacted by victim gender, while male participants generally held the defendant more responsible if the victim was male compared to female. A study on child sexual abuse found interactions between gender of the participant, victim, and defendant (Rogers \& Davies, 2007). Specifically, male participants rated a 15-year-old male victim as more responsible for the abuse when the act was perpetrated by a female defendant. Additionally, Plumm, Austin, and Terrance (2013) found that same-gendered student/teacher sexual assault offenses (i.e., male teacher and male student, female teacher and female student) were judged as more likely to have been committed and the 
defendant was viewed as more deserving of being on the sex offender registry. The results also suggested that victim blame was higher in instances of same-sex offenses.

\section{Gender of the Participant}

In addition to the interactive effects of participant and victim gender, it should be noted that meta-analytic evidence suggests that overall female jurors were more conviction-prone in cases of adult sexual assault and child sexual abuse than male jurors (Devine \& Caughlin, 2014). This may in part be due to female jurors having more empathy for the victim, more opposition to adult/child sex, and a tendency to believe children more in general than male jurors (Bottoms et al., 2014). In a study of student/teacher sexual assault, results suggested that female jurors perceived the victim to be more accurate, truthful, and believable and ascribed high responsibility ratings to the defendant in the case (Pozzulo et al., 2010). Altogether, more research is needed to explore the potential interactions of the gender of the defendant and victim, as well as gender of the participant.

\section{Teacher and Student Sexual Abuse Cases}

There is evidence that teacher/student sexual abuse cases affect a significant portion of school-aged children, making this topic in great need of examination. Of the seven studies conducted in the U.S., the prevalence rates of sexual misconduct by school staff range widely from $3.7 \%$ to $50.3 \%$ (Shakeshaft, 2004), including acts such as groping, exposure to sexual pictures, sexually-related conversations, and oral, anal, or vaginal penetration. Shakeshaft reported the most accurate data available suggests that $9.6 \%$ of students in grades 8 through 11 are victims of contact and/or noncontact sexual misconduct by an educator (American Association of University Women, 1993, 2001). Specifically, 8.7\% of students reported only noncontact offenses (i.e., no physical contact made) and 6.7\% reported contact offenses (i.e., 
involves some form of physical contact), with some students reporting both types of offenses. Of note, teachers were found to be the most common offenders for sexual misconduct (Shakeshaft, 2004). Of the school staff members who were prosecuted for these types of crimes, nearly half were accused of sexually inappropriate behaviors with more than one student (American Association of University Women, 1993). This issue of educator sexual abuse against students affects schools around the country, and has been reported in public and private, religious and secular, and urban and rural institutions. Importantly, many cases of this form of sexual abuse are never reported to authorities, making the actual prevalence of educator sexual misconduct likely higher than the current estimates.

Much focus has been placed on male teachers as responsible for educator sexual misconduct; however, there has been increased recognition of females who perpetrate these types of offenses (Thomas, 1999). In fact, almost half (43\%) of perpetrators of educator misconduct were female (American Association of University Women, 2001), which vastly contradicts the $5 \%$ prevalence of female perpetrators across all type of sexual offenses (Cortoni \& Hanson, 2005; Cortoni, Hanson, \& Coache, 2009). It has been proposed there is a specific typology of female sexual offenders called "teacher/lover", which described an adult female who perceives herself to be on the same emotional level as her younger victim, typically male (Matthews et al., 1991). The teacher/lover type is believed to seek out intimacy and fulfill sexual needs through the use of their position of trust (Simons, n.d.). These types of offenders view their actions as part of a consensual act and may not view the sexual behavior as inappropriate. It is suggested that these types of offenders result from poor attachment and problematic adult relationships.

Colson and colleagues (2013) stated that the idea of female sexual offenders has been met with much resistance and that this topic has been overlooked for many years. Thus, it is 
speculated that sexual offenses committed by females are especially likely to go underreported and underestimated (West, Friedman, \& Kim, 2011). This underreporting may be due to societal stereotypes regarding sexual offenders, clinical biases, issues with research methodologies, and dynamics of victim disclosure (Center for Sex Offender Management, 2007). In the case of sexual misconduct, the stereotype of female teachers being any male's fantasy may especially contribute to lack of reporting due to people not recognizing the act as a sexual offense or males not being viewed as victims. For example, a Thought Catalog article (Collins, 2017) described how a 25 -year-old female teacher was "seduc[ed]" by a 13-year-old male student, who was "flirty" and made "raunchy comments toward her" which resulted in her becoming "compliant" (Collins, 2017). This demonstrates the perception of female teachers having sexual relations with students may be viewed differently than other sexual offenses. All of this information taken together raises the importance of studying student/teacher sexual assault cases, given there are a significant number of students victimized and the perpetrators may be a unique population of sexual offenders.

\section{The Present Study}

Overall, meta-analytic evidence has shown that there is a relationship between attractiveness of a defendant, and guilt and sentencing decisions (Mazzella \& Feingold, 1994), including those recommended by jurors (e.g., Abwender \& Hough, 2001; Kerr, 1978; Kulka \& Kessler, 1978;

Solomon \& Schopler, 1978; Thornton, 1977; Wilson \& Donnerstein, 1977). This effect has been found in sexual offense cases, such as evidence showing lower guilt ratings (e.g., Castellow et al., 1990; Deitz \& Byrnes, 1981) and shorter sentences (e.g., Erian et al., 1998; Jacobson, 1981; Jacobson \& Popovich, 1983) for attractive defendants as compared to unattractive ones. There also appears to be increased leniency in sexual assault cases when the defendant is female versus 
male (e.g., Fallman \& Christianson, 1999; Howell et al., 2011; Quas et al., 2002). Moreover, there is evidence that the gender of the victim may also influence jurors, while sometimes interacting with other gender variables of the defendant and participant as well (i.e., Plumm et al., 2013; Rogers \& Davies, 2007). Previous research exploring the influence of attractiveness and gender on sexual-related crimes have methodological weaknesses, leaving an important gap in the literature to be filled. One such sexual crime in need of further research is teachers engaging in sexually inappropriate relationships with their students. There is a great need for research in this area since as many as $43 \%$ of teacher offenders are female (American Association of University Women, 2001) and it appears that the media portrays female teacher perpetrated crimes as the fulfillment of a sexual fantasy as opposed to a sexual assault against a minor. However, little is known about how these types of offenders are viewed in the court system, including how the person's gender and physical attractiveness may lead to harsh or lenient treatment. Therefore, further research is needed concerning teacher/student sexual assaults and the role these variables may play in juror decision-making in these cases.

The present study seeks to examine whether the physical attractiveness and gender of a teacher (i.e., the defendant), as well as the gender of the student (i.e., the alleged victim), impacts juror decision-making in a student/teacher sexual offense case. Specifically, it will examine how the aforementioned variables influence guilt determinations, sentencing decisions, perceptions of the teacher, and perceptions of the student. The present study had three primary aims: 1) examine the impact of attractiveness of the teacher; 2) examine the influence of gender of the teacher; and 3) examine the effect of gender of the student. It was hypothesized that:

1. The attractive teachers will be rated as less guilty and have shorter sentencing recommendations compared to the unattractive teachers. The attractive teachers are 
also expected to be viewed as less responsible for the act and more credible, in addition to eliciting higher levels of empathy from jurors.

2. Participants will ascribe more lenient guilt and sentencing ratings when the teacher is a female teacher compared to a male teacher, regardless of attractiveness ratings. The male teachers will be viewed as more responsible and less credible compared to the female teacher. Moreover, the participants will show less empathy for the male teacher compared to the female teacher.

3. Participants will rate offenders are more guilty and ascribe higher sentences in cases of female students compared to males. Further, female students will be perceived as less blameworthy and responsible, as well as more credible. Additionally, female students are anticipated to receive higher empathy ratings compared to male students.

The overall goal of this study is to gain a better understanding of how defendants in cases of teacher/student sexual assault are viewed by jurors, and how this influences guilt ratings and sentencing decisions. This will provide us vital information on how jurors may be making decisions in a sexual offense case with a teacher defendant, and whether the gender or attractiveness of the defendant impacts these decisions. Additionally, the study will explore whether victim gender has an impact on jurors' decisions. In all, the current study will significantly contribute to the field's knowledge regarding juror decision-making in sexual offense cases involving a teacher/student relationship. 


\section{CHAPTER 2}

\section{METHOD}

There are three parts to the current study. Part 1 utilized an undergraduate sample to identify which four photographs will be used in the larger study. Part 2 included a sample of undergraduate students in order to pilot the case vignettes to ensure variability in guilt ratings (i.e., to avoid a floor or ceiling effect). Part 3 investigated the main aims of the study using a representative community sample.

\section{Part 1}

Participants. A sample of 95 undergraduate students (29 males, 66 females) from a large urban university participated in the study to partially fulfill research credit requirements.

Individuals under the age of 18 were not eligible to participate in order to represent the actual age criteria for a potential U.S. juror member. The age ranged from $18-37$ years $(M=21.21)$. The participants were ethnically/racially diverse: Hispanic/Latino $(n=49)$, African American $(n=$ 13), White $(n=13)$, Biracial $(n=11)$, and Asian $(n=8)$.

This participant pool is believed to be representative of perceptions of attractiveness across various races, ages, and genders. First, studies have shown that attractiveness ratings do not vary as a function of the raters' gender (Korthase \& Trenholme, 1982; Grant, Button, Hannah, \& Ross, 2002). Second, research has examined the effect of the age of the rater on perceptions of attractiveness, revealing no differences in ratings of an individual's facial attractiveness based on rater age (Cross \& Cross, 1971). Third, prior studies have not found an own-race bias in attractiveness ratings, in that perceived levels of attractiveness do not differ based on the observers' or targets' race (Burke, Nolan, Hayward, Russell, \& Sulikowski, 2013). 
Taken together, the attractiveness ratings gathered from the sample in Part 1 of the study are expected to generalize to adult raters of all races, ages, and genders.

\section{Materials.}

Photographs. A series of 114 photographs (59 males, 55 females) were selected by the primary researcher from online databases of sex offender headshots. These photographs were colored headshots of male and female offenders with neutral backdrops.

Photograph Ratings. Participants are asked to rate each photograph on level of subjective attractiveness ( 1 = Very Unattractive, $3=$ Neutral, $5=$ Very Attractive $)$, facial expression (-2 = Negative Facial Expression, $0=$ Neutral, $2=$ Positive Facial Expression), and perceived age $(1=10-20$ years, $2=21-30$ years, $3=31-40$ years, $4=41-50$ years, $5=51$ and older).

Demographics. Participants were asked to report their age, gender, and race/ethnicity.

Procedure. Participants were first instructed to read the informed consent. If they agreed to participate in the study, participants were asked to rate each photograph for level of attractiveness, facial expression, and perceived age. The photographs were randomized for each participant in order to mitigate any impact order could have on ratings. Participants then completed demographic information. They were debriefed and thanked for their participation.

Statistical Analyses. Using the data collected from Part 1 of the study, the four photographs (i.e., attractive male, unattractive male, attractive female, unattractive female) to be utilized in Part 2 and Part 3 of the study were selected. Mean attractiveness ratings for each photograph were examined in order to select pairs of female and male photographs that represented opposite ends of the rating scale (e.g., an attractive female photograph as rated with 4.5 would be paired with an unattractive female photograph as rated with 1.5). Further, the 
ratings of the facial expression and age of individual were examined for each photograph to ensure there were no significant discrepancies when selecting the pairs.

The analyses resulted in the selection of four photographs. The pairings were all within 1.1 of the extreme end of the attractiveness rating scale (i.e., 1 being very unattractive and 5 being very attractive). The facial expressions all fell within the range of -1 to 1 , suggesting they were considered neutral. The age ratings were within the range of $1.5-2.5$, indicating perceived ages centered around 21-30 years old. Based on this data, it is believed the male and female photographs selected validity represent attractive and unattractive faces and do not significantly differ in facial expression or age. See Appendix A for the mean attractiveness, facial expression, and age ratings for the final photographs.

\section{Part 2}

Participants. A sample of 112 undergraduates (20 males, 92 female) from a large urban university participated in the study. Individuals under the age of 18 were not eligible to participate in order to represent the actual age criteria for a potential U.S. juror member. The ages ranged from 18-34 $(M=20.47)$. The participants were ethnically/racially diverse: Hispanic/Latino $(n=57)$, African American $(n=12)$, White $(n=25)$, Biracial $(n=1)$, Asian $(n=$ $14)$, and Other $(n=3)$.

\section{Materials.}

Vignettes. Participants were instructed to read one of six vignettes featuring a 35-year-old teacher accused of sexually assaulting a 14-year-old student. The average age of teachers who offend is approximately 37 years of age, and students are most at risk for abuse between ages 11 and 13 (Jaffe et al., 2013), justifying the use of the current ages. The vignettes were developed through a review of articles related to teacher/student sexual offenses and matched the 
information, style, and length of vignettes used in previous studies (e.g. Austin et al., 2013). See Appendix B for the pilot vignette. The attractive and unattractive male and female photographs were selected based on data from Part 1. The no photograph conditions serve as control conditions given that physical attractiveness was not manipulated. Of note, the variable of student gender was not utilized when piloting the data, as this is an additional variable of interest in Part 3 though is not the primary aim of the study. Thus, only opposite sex student/teacher vignettes were used to pilot the case vignettes. The six conditions are described below:

1) Attractive Male Teacher- Attractive male teacher accused of statutory rape of a female student.

2) Unattractive Male Teacher- Unattractive male teacher accused of statutory rape of a female student.

3) No photograph Male Teacher- Male teacher accused of statutory rape of a female student, appearance unknown.

4) Attractive Female Teacher- Attractive female teacher accused of statutory rape of a male student.

5) Unattractive Female Teacher- Unattractive female teacher accused of statutory rape of a male student.

6) No photograph Female Teacher- Female teacher accused of statutory rape of a male student, appearance unknown.

Extent of Guilt. Participants rated their extent of guilt $(1=$ Not at all, $10=$ Completely $)$.

Demographics. Participants were asked to report their age, gender, and race/ethnicity.

Procedure. Participants were first instructed to read the informed consent. If they agreed to participant in exchange for course credit, they were randomly assigned to read one of the six 
vignettes. Participants rated their extent of guilt after reading the vignette. Upon completion of this portion, participants then reported demographic information and were debriefed and thanked for their participation in the study.

Data Analyses. A two-way ANOVA was conducted to examine the effect of attractiveness and gender of the perpetrator on extent of guilt ratings. There was not a significant interaction between the effects of attractiveness and gender on guilt ratings, $F(2,106)=.29, p=$ .749. Further, there were no significant main effects for attractiveness level, $F(2,106)=$ $1.13, p=.327$, or gender, $F(1,106)=.75, p=.387$. The mean guilt ratings for the conditions are reported in Table 1. Of note, while the statistical analyses were not significant, the data appears to be trending in the hypothesized direction. Of most importance for the purpose of Part 2 of the study, the data shows variability in responding. However, in order to obtain guilt ratings that fall more closely toward the middle of the extent of guilt scale (i.e., mean of 5), one sentence was added to the vignette ("According to one of the student's teachers, he/she has recently appeared distressed in school and his/her grades have been declining. The student denied any current problems when asked by the teacher.") and the child's age was lowered (i.e., from age 14 to 13), which are both expected to slightly increase guilt ratings. See Appendix C for the final vignette that was used in Part 3.

\section{Part 3}

Participants. Participants were individuals ages 18 or above who volunteered through the website Amazon Mechanical Turk. Mechanical Turk is a public, online survey site community in which people can sign up to participate in studies for monetary compensation. Mechanical Turk has been found to produce high-quality data (Buhrmester, Kwang, \& Gosling, 2011). A brief description of the study was posted on Mechanical Turk and individuals had the 
opportunity to sign up to participate in the study. Individuals were required to be U.S. citizens (currently residing in the U.S.) and over the age of 18 to participate (i.e., jury eligible); this information was obtained based on demographics participants provided to Mechanical Turk. Participants who volunteered to take the online survey were awarded a monetary value of $\$ 1.40$. Studies have shown this price of $\$ 1.38$ to maximize valid data (Horton \& Chilton, 2010). A power analysis indicated that 672 participants will be needed to detect a medium effect size for this portion of the study. However, due to the likelihood of invalid or missing data, 1,168 participants were recruited. Incomplete and duplicate (i.e., the same participant completed the survey more than once) data were removed from the data set $(n=163)$. If the survey was completed by the same participant more than one time, the first attempt was retained and the subsequent attempts were removed. Additionally, any participants who did not pass all three manipulation check questions following the vignette were removed from the dataset $(n=64)$.

The final sample following data cleaning was 1,104 individuals ages 18-77 $(M=35.69$ years). In regards to gender, the sample was comprised of 506 males, 593 females, and 5 people who identified as "other." The majority of the sample identified as White $(n=838)$, with the remainder identifying as African American $(n=93)$, Asian $(n=70)$, Hispanic or Latino $(n=65)$, Biracial $(n=31)$, and "other" $(n=7)$. Participants were asked if they have been a victim of child sexual abuse themselves, with 141 reporting they had been victimized, 23 preferred not to answer, and 940 denied a history of victimization.

\section{Materials.}

Vignettes. Participants were randomly assigned to read one of twelve, one-page vignettes. The photographs coupled with the vignettes were selected based on participant ratings from Part 1 and 2. The twelve vignettes represented a 2 (Teacher Gender: Male/Female) by 2 (Student 
Gender: Male/Female) by 3 (Attractiveness Level: Attractive/Unattractive/No Photo) design. The vignettes are described below:

1) Attractive Male Teacher- Attractive male teacher accused of statutory rape of a female student.

2) Attractive Male Teacher- Attractive male teacher accused of statutory rape of a male student.

3) Unattractive Male Teacher- Unattractive male teacher accused of statutory rape of a female student.

4) Unattractive Male Teacher- Unattractive male teacher accused of statutory rape of a male student.

5) No photograph Male Teacher- Male teacher accused of statutory rape of a female student, appearance unknown.

6) No photograph Male Teacher- Male teacher accused of statutory rape of a male student, appearance unknown.

7) Attractive Female Teacher- Attractive female teacher accused of statutory rape of a male student.

8) Attractive Female Teacher- Attractive female teacher accused of statutory rape of a female student.

9) Unattractive Female Teacher- Unattractive female teacher accused of statutory rape of a male student

10) Unattractive Female Teacher- Unattractive female teacher accused of statutory rape of a female student 
11) No photograph Female Teacher- Female teacher accused of statutory rape of a male student, appearance unknown.

12) No photograph Female Teacher- Female teacher accused of statutory rape of a female student, appearance unknown.

Manipulation Check Questions. Participants were asked three manipulation questions after reading their assigned vignette to ensure comprehension of the material (i.e., gender of the defendant, gender of the student, type of crime committed). Participants who had difficulty reading were be screened out through the manipulation check questions as well. See questions 1 through 3 in Appendix D. It should also be noted that a question was embedded in the survey inquiring about the level of physical attractiveness of the defendant $(1=$ not at all, $10=$ very; see question 27 in Appendix D). This question was used to gauge whether the manipulation of physical attractiveness using the selected photographs was in the predicted direction.

Guilt Determinations. Participants were asked to answer several questions related to Guilt Determinations (i.e., providing a verdict, rating the extent of guilt, rating their confidence, and rating the likelihood a sexual offense was committed). See questions 4 through 7 in Appendix D.

Sentencing Decisions. If the participant voted guilty, they were asked to respond to questions related to Sentencing Decisions. These questions included: what the appropriate sentence length should be, whether the defendant is likely to commit another crime, whether they should have to register as a sex offender (and for how long), whether they should be mandated to treatment, and whether they should be subject to community notification. See questions 8 through 13 in Appendix D.

Perceptions of the Teacher and Student. Next, all participants (regardless of verdict) were asked a series of questions related to the Perceptions of the Teacher and Perceptions of the 
Student. The questions related to perceptions of the teacher and student were derived from prior research on juror decision-making (e.g., Ahola, et al., 2009; Austin et al., 2013), as well as created for the purpose of the present study. These included questions related to responsibility, credibility, and empathy for both the defendant and victim. Participants also responded to a series of questions related to the blameworthiness of the victim.

Several scales were created based on the data obtained from the questions related to the Perceptions of the Teacher and Perceptions of the Student. First, a Teacher Responsibility (see questions 15 through 17 in Appendix D; Cronbach's $\alpha=.93$ ) and Student Responsibility (see questions 18 through 20 in Appendix D; Cronbach's $\alpha=.90$ ) scale were created (scores range 330), to examine the extent to which participants believed the teacher and student were at fault. Second, each participant received a Teacher Credibility (see questions 23 through 26 in Appendix D; Cronbach's $\alpha=.94$ ) and Student Credibility (see questions 28 through 31 in Appendix D; Cronbach's $\alpha=.94$ ) scale (scores range 4-40), in order to examine the extent to which the participants believed in and trusted the teacher's and student's view. Third, participants ratings on three questions regarding their ability to empathize with the teacher and student will be summed to create a Teacher Empathy (see questions 21a through 21c in Appendix D; Cronbach's $\alpha=.94$ ) and a Student Empathy (see questions 22a through 22c in Appendix D; Cronbach's $\alpha=.94$ ) scale (scores range 3-30). Fourth, Participants were asked six questions regarding their level of blame for the victim utilized from a prior study (Austin et al., 2013; see questions 14a through 14f in Appendix D), which will be summed for a total score of Student Blameworthiness (score range 6-60; Cronbach's $\alpha=.81$ ). All of the Cronbach's $\alpha$ results suggest the scales had high internal consistency. 
Demographic Questionnaire. Participants answered a series of demographic questions (i.e., age, gender, race/ethnicity, history of sexual victimization). See Appendix E for the demographic questionnaire.

Procedure. Participants who signed up for the study read the informed consent. If they agreed to participate, they were randomly assigned to read one of the twelve vignettes. After reading the information about the case, participants were asked three manipulation check questions. Participants were asked to provide decisions related to the case, including guilt determinations and sentencing decisions. Further, they responded to questions inquiring about their perceptions of the teacher and student. Finally, the participant answered demographic questions. They were thanked, debriefed, and awarded a monetary value of $\$ 1.40$ through Mechanical Turk. 


\section{CHAPTER 3}

\section{RESULTS}

Analyses for Part 3 of the study were based on a 2 (Teacher Gender: Male/Female) by 2 (Student Gender: Male /Female) by 3 (Attractiveness Level: Attractive/Unattractive/No Photo) design. For all analyses, the assumptions of these tests (e.g., absence of outliers, homogeneity of variance, normality) were examined prior to running analyses, and any violations resulted in subsequent determinations of the appropriate analysis given the data. It should also be noted that the sentencing variables were only analyzed for those participants who provided a verdict of guilty, as the questions assumed guilt.

\section{Demographic Differences}

Analyses were conducted on demographic information between conditions to examine any group differences. Results suggested the twelve groups were not significantly different from one another in terms of gender $\left[\chi^{2}(22)=23.46, p=.376\right]$, age $[F(11,1092)=1.20, p=.285]$, race $\left[\chi^{2}(55)=45.99, p=.801\right]$, or sexual victimization history $\left[\chi^{2}(22)=19.28, p=.63\right]$. Therefore, these variables were not included in subsequent analyses, aside from the use of participant gender in exploratory analyses related to verdict, extent of guilt, and student empathy.

\section{Attractiveness Manipulation}

In order to examine the attractiveness level manipulation check, a one-way ANOVA was conducted to explore whether the physical attractiveness manipulation was successful (i.e., ratings of attractiveness for the teacher should significantly differ across Attractiveness Level conditions). The assumptions of a one-way ANOVA were examined to explore the influence of Attractiveness Level on Teacher Attractiveness ratings. A series of boxplots revealed several outliers and the Shapiro-Wilk's Tests of Normality were significant for all groups $(p<.01)$. 
Moreover, Levene's Test of Homogeneity of Variance $(p<.01)$ was violated; therefore, the nonparametric Krustal-Wallis H test was used. The Teacher Attractiveness ratings differed significantly between Attractiveness Level, Welch's $F(2,725.76)=117.01, p<.001$. Teacher Attractiveness scores increased from the unattractive group $(M=3.69, S D=2.197)$ to the no photo group $(M=4.88, S D=1.77)$ to the attractive group $(M=6.32, S D=2.55)$. Results from Games-Howell post hoc analyses revealed significant differences between all of the groups. The mean increase from the unattractive to no photo $(1.20,95 \% \mathrm{CI}[.85,1.54])$, no photo to attractive $(1.44,95 \% \mathrm{CI}[1.05,1.82])$, and unattractive to attractive $(2.63,95 \% \mathrm{CI}[2.23,3.04])$ were all statistically significant $(p<.001)$. Thus, it can be concluded that the manipulation check on the Attractiveness Level was successful, in that the Teacher Attractiveness ratings varied depending on the manipulation of attractiveness between conditions in the expected direction.

\section{Guilt Determinations}

Verdict. A binomial logistic regression was conducted to examine the impact of Attractiveness Level, Teacher Gender, Student Gender, and Participant Gender on the likelihood of a guilty verdict. One categorical variable category had a low count (Participant Gender: "other" was $n=5$ ), therefore these cases were excluded as a low group $n$ is undesirable for a binomial logistic regression. The assumption of multicollinearity was examined through inspection of the Tolerance/VIF values of the independent variables, which suggested there were no issues with multicollinearity.

Overall, there were $25.6 \%$ guilty and $74.4 \%$ not guilty verdicts. The logistic regression model was not statistically significant, $\chi^{2}(5)=6.45, p=.263$. The model only explained $0.9 \%$ of the variance (Nagelkerke $R^{2}=.009$ ). The model correctly classified $74.5 \%$ of the cases, compared to classification of $74.5 \%$ in the absence of the independent variables, suggesting the 
independent variables did not contribute to predictive value. Sensitivity (i.e., the percentage of cases in which the guilty verdict was correctly predicted by the model) was $0.0 \%$. Specificity (i.e., the percentage of cases in which the not guilty verdict was correctly predicted by the model) was $100 \%$. The positive predictive value (i.e., the percentage of correctly predicted cases of a guilty verdict compared to total number cases predicted as guilty) was $0.0 \%$. The negative predictive value (i.e., the percentage of correctly predicted cases of a not guilty verdict compared to the total number of cases predicted as not guilty) was $74.5 \%$. Of the predictor variables, only Participant Gender was significant (See Table 2). Female participants had 1.32 times higher odds of voting guilty compared to males. There was no significant difference between participants voting guilty for the male defendant (14.4\%) compared to the female defendant $(11.2 \%)$.

Extent of Guilt. A three-way ANOVA was conducted to examine the impact of Attractiveness Level, Teacher Gender, and Student Gender on Extent of Guilt ratings. The assumptions of a three-way ANOVA were examined. While there were several outliers in dependent variable ratings that were identified using boxplots, these points were retained given they were within the range of possible responses (i.e., scale of 1-10). Shapiro-Wilk's tests of normality were significant for all conditions $(p<.05)$, suggesting the data was not normally distributed. However, given the large sample size, it was determined that it is appropriate to proceed with the three-way ANOVA analysis given the robust nature of the analysis (Laerd Statistics, 2017). It should be noted that the decision to continue conducting a three-way ANOVA in the presence of violations of outliers and issues with normality was retained through all subsequent analyses of the continuous dependent variables.

Levene's Test of Equality of Error Variances in this case was not significant, $p=.436$, indicating that there was homogeneity of variances. The results of the three-way ANOVA 
indicated there was no statistically significant three-way interaction between Attractiveness Level, Teacher Gender, and Student Gender, $F(2,1092)=1.13, p=.325$, partial $\eta^{2}=.25$. The mean guilt ratings for all conditions are reported in Table 3. The two-way interactions for Attractiveness Level and Teacher Gender $\left[F(2,1092)=2.44, p=.088\right.$, partial $\left.\eta^{2}=.49\right]$, Attractiveness Level and Student Gender $\left[F(2,1092)=.67, p=.514\right.$, partial $\left.\eta^{2}=.16\right]$, and Teacher Gender and Student Gender $\left[F(1,1092)=1.65, p=.199\right.$, partial $\left.\eta^{2}=.25\right]$ were not significant. The main effect for Teacher Gender was significant $[F(1,1092)=10.11, p=.002$, partial $\eta^{2}=.89$ ], with the male teacher receiving higher extent of guilt ratings comparing to the female teacher. The main effect for Level of Attractiveness $[F(2,1092)=1.36, p=.256$, partial $\left.\eta^{2}=.30\right]$ and Student Gender $\left[F(1,1092)=2.77, p=.096\right.$, partial $\left.\eta^{2}=.38\right]$ were not significant.

Given there is some prior evidence of interaction with Participant Gender on Attractiveness Level and Teacher Gender (e.g., Abwender \& Hough, 2001, Thornton, 1977, Wuensch et al., 1991), a second three-way ANOVA was conducted to examine the impact of Attractiveness Level, Teacher Gender, and Participant Gender on Extent of Guilt ratings. There were no outliers and Shapiro-Wilk was significant for all groups $(p<.05)$. Levene's Test of Equality of Error Variances was not significant, $p=.406$, revealing there was homogeneity of variances. Results indicated there was no significant three-way interaction, $F(2,1089)=.02, p=$ .985 , partial $\eta^{2}=.05$. The mean guilt ratings for all conditions are reported in Table 4 . There were no significant two-way interactions between Attractiveness Level and Teacher Gender $\left[F(2,1089)=2.06, p=.128\right.$, partial $\left.\eta^{2}=.43\right]$, Attractiveness Level and Participant Gender $[F(3$, $1089)=.40, p=.751$, partial $\left.\eta^{2}=.13\right]$, and Teacher Gender and Participant Gender, $[F(1,1089)$ $=2.20, p=.138$, partial $\left.\eta^{2}=.32\right]$. The main effect for Teacher Gender was significant, $F(1$, 1089) $=9.47, p=.002$, partial $\eta^{2}=.87$, with the male teacher receiving higher extent of guilt 
ratings compared to the female teacher. The main effect for Participant Gender was also significant, $F(2,1089)=5.83, p=.003$, partial $\eta^{2}=.87$. Tukey HSD post hoc analyses revealed females had significantly higher extent of guilt ratings compared to males. The "other" gender category did not significantly differ from males or females. The main effect for Level of Attractiveness was not significant, $F(2,1092)=1.30, p=.274$, partial $\eta^{2}=.28$.

Given that the Participant Gender did not interact with the other main variables in the study and is not the primary focus of the present analyses, the variable was not included in subsequent analyses unless otherwise noted.

Confidence. A three-way ANOVA was analyzed to examine the impact of Attractiveness Level, Teacher Gender, and Student Gender on Confidence ratings. The tests of assumptions found several outliers and the Shapiro-Wilk's test of normality were significant for conditions ( $p$ $<.05)$. Levene's Test of Equality of Error Variances was not significant, $p=.304$, suggesting that there was homogeneity of variances.

The results of the three-way ANOVA indicated there was no statistically significant three-way interaction, $F(2,1092)=.01, p=.987$, partial $\eta^{2}=.05$. The mean confidence ratings for all conditions are reported in Table 5. There were no significant two-way interactions between Attractiveness Level and Teacher Gender $\left[F(2,1092)=1.18, p=.309\right.$, partial $\left.\eta^{2}=.26\right]$, Attractiveness Level and Student Gender $\left[F(2,1092)=.62, p=.537\right.$, partial $\left.\eta^{2}=.16\right]$, and Teacher Gender and Student Gender, $\left[F(1,1092)=.58, p=.445\right.$, partial $\left.\eta^{2}=.12\right]$. The main effect for Teacher Gender was significant $\left[F(1,1092)=5.15, p=.023\right.$, partial $\left.\eta^{2}=.62\right]$, with higher confidence ratings for the female teacher compared to male teacher. The main effects for Level of Attractiveness $\left[F(2,1092)=.37, p=.694\right.$, partial $\left.\eta^{2}=.11\right]$ and Student Gender $[F(1$, $1092)=.004, p=.950$, partial $\left.\eta^{2}=.05\right]$ were not significant. 
In order to better understand the Teacher Gender main effect for the Confidence ratings, two one-way ANOVAs were conducted for each verdict using Teacher Gender as the independent variable. First, an ANOVA was analyzed only with guilty verdicts, which was not significant, $\left[F(1,281)=.01, p=.915\right.$, partial $\left.\eta^{2}=.00\right]$, showing no differences between the male teacher $(M=7.58, S D=2.40)$ and female teacher $(M=7.55, S D=2.29)$. Second, an ANOVA was conducted with only the not guilty verdicts, which revealed a significant result, $F(1,819)=$ $8.12, p=.004$, partial $\eta^{2}=.01$, with participants having significantly higher confidence ratings with the female teacher $(M=7.18, S D=2.32)$ than the male teacher $(M=6.71, S D=2.39)$.

Belief that a Sexual Offense was Committed. A three-way ANOVA was analyzed to examine the impact of Attractiveness Level, Teacher Gender, and Student Gender on Belief that a Sex Offense was Committed ratings. The tests of assumptions found several outliers and the Shapiro-Wilk's test of normality were significant for all conditions $(p<.05)$. Levene's Test of Equality of Error Variances was not significant, $p=.934$, indicating that there was homogeneity of variances.

The results of the three-way ANOVA found no statistically significant three-way interaction, $F(2,1092)=1.84, p=.160$, partial $\eta^{2}=.38$. The mean belief ratings for all conditions are reported in Table 6. There were no significant two-way interactions for Attractiveness Level and Teacher Gender $\left[F(2,1092)=2.40, p=.092\right.$, partial $\left.\eta^{2}=.49\right]$, Attractiveness Level and Student Gender $\left[F(2,1092)=.74, p=.476\right.$, partial $\left.\eta^{2}=.18\right]$, and Teacher Gender and Student Gender $\left[F(1,1092)=3.42, p=.065\right.$, partial $\left.\eta^{2}=.46\right]$. The main effect for Teacher Gender was significant, $F(1,1092)=11.54, p=.001$, partial $\eta^{2}=.92$, with higher belief a sex offense was committed for the male teacher compared to the female teacher. 
The main effects for Level of Attractiveness $\left[F(2,1092)=.30, p=.739\right.$, partial $\left.\eta^{2}=.10\right]$ and Student Gender $\left[F(1,1092)=.10, p=.758\right.$, partial $\left.\eta^{2}=.06\right]$ were not significant.

\section{Sentencing}

Sentence Length. Three chi-square analyses were conducted to examine the effect of Attractiveness Level, Teacher Gender, and Student Gender on Sentence Length determinations. There were no significant effects for Attractiveness $\left[\chi^{2}(14)=18.55, p=.183\right]$, Teacher Gender $\left[\chi^{2}(7)=12.32, p=.091\right]$, and Student Gender $\left[\chi^{2}(7)=3.93, p=.788\right]$ on sentence length.

Likelihood of Reoffending. A three-way ANOVA was analyzed to examine the impact of Attractiveness Level, Teacher Gender, and Student Gender on Likelihood of Reoffending ratings. The tests of assumptions found several outliers and the Shapiro-Wilk's test of normality were significant for 7 of 12 conditions $(p<.05)$. Levene's Test of Equality of Error Variances was not significant, $p=.589$, suggesting there was homogeneity of variances.

The results of the three-way ANOVA revealed there was no statistically significant threeway interaction, $F(2,271)=1.48, p=.230$, partial $\eta^{2}=.31$. The mean likelihood ratings for all conditions are reported in Table 7. There were no significant two-way interactions between Attractiveness Level and Teacher Gender $\left[F(2,271)=.48, p=.619\right.$, partial $\left.\eta^{2}=.13\right]$, Attractiveness Level and Student Gender $\left[F(2,271)=.04, p=.957\right.$, partial $\left.\eta^{2}=.06\right]$, and Teacher Gender and Student Gender, $\left[F(1,271)=3.14, p=.077\right.$, partial $\left.\eta^{2}=.42\right]$. The main effects for Attractiveness Level $\left[F(2,271)=.04, p=.957\right.$, partial $\left.\eta^{2}=.06\right]$, Teacher Gender $\left[F(1,271)=2.91, p=.089\right.$, partial $\left.\eta^{2}=.40\right]$, and Student Gender $[F(1,271)=.04, p=843$, partial $\left.\eta^{2}=.05\right]$ were not significant.

Sex Offender Registration. A three-way ANOVA was conducted to explore the impact of Attractiveness Level, Teacher Gender, and Student Gender on Sex Offender Registration 
ratings. The tests of assumptions found several outliers and the Shapiro-Wilk's test of normality were significant for conditions $(p<.05)$. Levene's Test of Equality of Error Variances was significant, $p=.041$, indicating that there was not homogeneity of variances. As noted earlier, the robustness of the three-way ANOVA allowed for the continued analysis.

The results of the three-way ANOVA indicated there was no statistically significant three-way interaction, $F(2,271)=.08, p=.927$, partial $\eta^{2}=.06$. The mean registration ratings for all conditions are reported in Table 8. There were no significant two-way interactions between Attractiveness Level and Teacher Gender $\left[F(2,271)=.15, p=.861\right.$, partial $\left.\eta^{2}=.07\right]$, Attractiveness Level and Student Gender $\left[F(2,271)=.94, p=.392\right.$, partial $\left.\eta^{2}=.21\right]$, and Teacher Gender and Student Gender, $\left[F(1,271)=.63, p=.429\right.$, partial $\left.\eta^{2}=.12\right]$. The main effects for Attractiveness Level $\left[F(2,271)=1.00, p=.369\right.$, partial $\left.\eta^{2}=.22\right]$, Teacher Gender $\left[F(1,271)=.16, p=.686\right.$, partial $\left.\eta^{2}=.07\right]$, and Student Gender $[F(1,271)=.001, p=.976$, partial $\left.\eta^{2}=.05\right]$ were not significant.

Length of Sex Offender Registration. Three chi-square analyses were conducted to examine the effect of Attractiveness Level, Teacher Gender, and Student Gender on Length of Sex Offender Registration determinations. There were no significant effects for Attractiveness Level $\left[\chi^{2}(6)=3.08, p=.799\right]$, Teacher Gender $\left[\chi^{2}(3)=7.65, p=.054\right]$, and Student Gender $\left[\chi^{2}\right.$ (3) $=2.75, p=.432]$ on sex offender registration length.

Sex Offender Treatment. A three-way ANOVA was analyzed to explore the impact of Attractiveness Level, Teacher Gender, and Student Gender on Sex Offender Treatment ratings. The tests of assumptions found several outliers and the Shapiro-Wilk's test of normality were significant for 11 or 12 conditions $(p<.05)$. Levene's Test of Equality of Error Variances was not significant, $p=.545$, indicating that there was homogeneity of variances. 
The results of the three-way ANOVA indicated there was no statistically significant three-way interaction, $F(2,271)=.31, p=.731$, partial $\eta^{2}=.10$. The mean length ratings for all conditions are reported in Table 9. There were no significant two-way interactions between Attractiveness Level and Teacher Gender $\left[F(2,271)=.16, p=.851\right.$, partial $\left.\eta^{2}=.08\right]$, Attractiveness Level and Student Gender $\left[F(2,271)=.21, p=.810\right.$, partial $\left.\eta^{2}=.08\right]$, and Teacher Gender and Student Gender, $\left[F(1,271)=.01, p=.908\right.$, partial $\left.\eta^{2}=.05\right]$. The main effect for Attractiveness Level was significant $\left[F(2,271)=3.12, p=.046\right.$, partial $\left.\eta^{2}=.60\right]$. The no photo condition had significantly higher ratings compared to both the attractive and unattractive conditions; the attractive and unattractive conditions did not differ. The main effects for Teacher Gender $\left[F(1,271)=.29, p=.594\right.$, partial $\left.\eta^{2}=.08\right]$ and Student Gender $[F(1,271)=.30, p=$ .086 , partial $\left.\eta^{2}=.40\right]$ were not significant.

Community Notification. A three-way ANOVA was analyzed to examine the impact of Attractiveness Level, Teacher Gender, and Student Gender on Community Notification ratings. The tests of assumptions found several outliers and the Shapiro-Wilk's test of normality were significant for all conditions $(p<.05)$. Levene's Test of Equality of Error Variances was not significant, $p=.094$, indicating that there was homogeneity of variances.

The results of the three-way ANOVA indicated there was no statistically significant three-way interaction, $F(2,271)=.04, p=.966$, partial $\eta^{2}=.06$. The mean notification ratings for all conditions are reported in Table 10. There were no significant two-way interactions between Attractiveness Level and Teacher Gender $\left[F(2,271)=.39, p=.681\right.$, partial $\left.\eta^{2}=.11\right]$, Attractiveness Level and Student Gender $\left[F(2,271)=.25, p=.776\right.$, partial $\left.\eta^{2}=.09\right]$, and Teacher Gender and Student Gender, $\left[F(1,271)=.37, p=.542\right.$, partial $\left.\eta^{2}=.09\right]$. The main effects for Attractiveness Level $\left[F(2,271)=1.92, p=.149\right.$, partial $\left.\eta^{2}=.40\right]$, Teacher Gender 
$\left[F(1,271)=.19, p=.663\right.$, partial $\left.\eta^{2}=.07\right]$, and Student Gender $[F(1,271)=.84, p=.361$, partial $\left.\eta^{2}=.15\right]$ were not significant.

\section{Perceptions of the Teacher}

Teacher Responsibility. A three-way ANOVA was analyzed to examine the impact of Attractiveness Level, Teacher Gender, and Student Gender on ratings of Teacher Responsibility ratings. The tests of assumptions found there was no outliers. The Shapiro-Wilk's test of normality were significant for all conditions $(p<.05)$. Levene's Test of Equality of Error Variances was not significant, $p=.725$, indicating that there was homogeneity of variances.

The results of the three-way ANOVA indicated there was no statistically significant three-way interaction, $F(2,1092)=.03, p=.967$, partial $\eta^{2}=.06$. The mean teacher

responsibility ratings for all conditions are reported in Table 11. There was a significant two-way interaction between Teacher Gender and Student Gender, $F(1,1092)=6.11, p=.014$, partial $\eta^{2}$ $=70$. Teacher Responsibility ratings were significantly affected by Teacher Gender for the female student $\left[F(1,1092)=17.16, p<.001\right.$, partial $\left.\eta^{2}=.99\right]$, but not for the male student $[F(1$, $1092)=.51, p=.477$, partial $\left.\eta^{2}=.11\right]$. Pairwise comparisons were made for the female student with a Bonferroni Adjustment. The Teacher Responsibility ratings for the male teacher were significantly higher than the female teacher (See Figure 1). The simple main effect of Student Gender on mean Teacher Responsibility ratings was statistically significant for the female teacher $\left[F(1,1092)=5.20, p=.023\right.$, partial $\left.\eta^{2}=.63\right]$, but not for the male teacher $[F(1,1092)=$ $1.41, p=.235$, partial $\left.\eta^{2}=.22\right]$. Pairwise comparisons were made for the female teacher with a Bonferroni Adjustment. The Teacher Responsibility ratings for the male student were significantly higher than the female student (See Figure 1). 
There were no significant two-way interactions between Attractiveness Level and Teacher Gender $\left[F(2,1092)=.05, p=.949\right.$, partial $\left.\eta^{2}=.06\right]$ and Attractiveness Level and Student Gender $\left[F(2,1092)=1.93, p=.145\right.$, partial $\left.\eta^{2}=.40\right]$. The main effect for Teacher Gender was significant $\left[F(1,1092)=11.99, p=.001\right.$, partial $\left.\eta^{2}=.93\right]$, with the male teacher receiving significant higher ratings of responsibility compared to the female teacher (See Table 11 for means). The main effects for Attractiveness Level $\left[F(2,1092)=.19, p=.831\right.$, partial $\eta^{2}=$ $.08]$ and Student Gender $\left[F(1,1092)=.69, p=.406\right.$, partial $\left.\eta^{2}=.13\right]$ were not significant.

Teacher Credibility. A three-way ANOVA was analyzed to examine the impact of Attractiveness Level, Teacher Gender, and Participant Gender on Teacher Credibility ratings. The tests of assumptions found there were no outliers. The Shapiro-Wilk's test of normality were significant for 9 of 12 conditions $(p<.05)$. Levene's Test of Equality of Error Variances was not significant, $p=.336$, indicating that there was homogeneity of variances.

The results of the three-way ANOVA indicated there was no statistically significant three-way interaction, $F(2,1092)=2.67, p=.070$, partial $\eta^{2}=.53$. The mean teacher credibility ratings for all conditions are reported in Table 12. There was a significant two-way interaction between Attractiveness and Teacher Gender, $F(1,1092)=4.34, p=.013$, partial $\eta^{2}=.75$. The simple main effect of Teacher Gender on mean Teacher Credibility ratings was statistically significant for the no photo condition $\left[F(1,1092)=20.34, p<.001\right.$, partial $\left.\eta^{2}=.99\right]$, but not for the attractive $\left[F(1,1092)=1.27, p=.259\right.$, partial $\left.\eta^{2}=.20\right]$ or unattractive $[F(1,1092)=1.00, p=$ .317 , partial $\left.\eta^{2}=.17\right]$ conditions. Pairwise comparisons were made for the no photo condition with a Bonferroni Adjustment. The Teacher Credibility ratings for the female teacher was significantly higher than the male teacher (See Figure 2). The simple main effect of Attractiveness Level on mean Teacher Credibility ratings was statistically significant for the 
female teacher $\left[F(2,1092)=3.77, p=.023\right.$, partial $\left.\eta^{2}=.69\right]$, but not for the male teacher $[F(2$, 1092) $=1.07, p=.342$, partial $\left.\eta^{2}=.24\right]$. Pairwise comparisons were made for the female teacher with a Bonferroni Adjustment. The Teacher Credibility ratings for the no photo condition was significantly higher than the unattractive condition. There were no significant differences between attractive and the no photo or unattractive conditions (See Figure 2).

There were no significant two-way interactions between Attractiveness Level and Student Gender $\left[F(2,1092)=2.58, p=.077\right.$, partial $\left.\eta^{2}=.52\right]$ and Teacher Gender and Student Gender $\left[F(1,1092)=1.52, p=.217\right.$, partial $\left.\eta^{2}=.23\right]$. The main effect for Teacher Gender was significant $\left[F(1,1092)=15.44, p<.001\right.$, partial $\left.\eta^{2}=.98\right]$, with the female teacher receiving significantly higher ratings of credibility compared to the male teacher (See Table 12 for means). The main effects for Attractiveness Level $\left[F(2,1092)=.57, p=.564\right.$, partial $\left.\eta^{2}=.15\right]$ and Student Gender $\left[F(1,1092)=.35, p=.555\right.$, partial $\left.\eta^{2}=.09\right]$ were not significant.

Teacher Empathy. A three-way ANOVA was analyzed to examine the impact of Attractiveness Level, Teacher Gender, and Student Gender on Teacher Empathy ratings. The tests of assumptions found there were no outliers. The Shapiro-Wilk's test of normality were significant for all conditions $(p<.05)$. Levene's Test of Equality of Error Variances was not significant, $p=.102$, indicating that there was homogeneity of variances.

Results revealed there was no statistically significant three-way interaction, $F(2,1092)=$ $2.51, p=.082$, partial $\eta^{2}=.50$. The mean teacher empathy ratings for all conditions are reported in Table 13. There were no significant two-way interactions between Attractiveness Level and Teacher Gender $\left[F(2,1092)=.72, p=.489\right.$, partial $\left.\eta^{2}=.17\right]$, Attractiveness Level and Student Gender $\left[F(2,1092)=.17, p=.845\right.$, partial $\left.\eta^{2}=.08\right]$, and Teacher Gender and Student Gender, $\left[F(1,1092)=2.80, p=.095\right.$, partial $\left.\eta^{2}=.39\right]$. The main effect for Level of Attractiveness $[F(2$, 
$1092)=1.24, p=.291$, partial $\left.\eta^{2}=.27\right]$, Teacher Gender $\left[F(1,1092)=1.95, p=.163\right.$, partial $\eta^{2}$ $=.29]$, and Student Gender $\left[F(1,1092)=.28, p=.598\right.$, partial $\left.\eta^{2}=.08\right]$ were not significant.

\section{Perceptions of the Student}

Student Blameworthiness. A three-way ANOVA was analyzed to examine the impact of Attractiveness Level, Teacher Gender, and Student Gender on Student Blameworthiness ratings. The tests of assumptions found several outliers and the Shapiro-Wilk's test of normality were significant for all conditions $(p<.05)$. Levene's Test of Equality of Error Variances was not significant, $p=.850$, indicating that there was homogeneity of variances.

The results of the three-way ANOVA indicated there was no statistically significant three-way interaction, $F(2,1092)=.11, p=.897$, partial $\eta^{2}=.07$. The mean student blameworthiness ratings for all conditions are reported in Table 14. There were no significant two-way interactions between Attractiveness Level and Teacher Gender $[F(2,1092)=.01, p=$ .988 , partial $\left.\eta^{2}=.05\right]$, Attractiveness Level and Student Gender $[F(2,1092)=.18, p=.836$, partial $\left.\eta^{2}=.08\right]$, and Teacher Gender and Student Gender, $\left[F(1,1092)=2.25, p=.134\right.$, partial $\eta^{2}$ $=.32]$. The main effects for Attractiveness Level $\left[F(2,1092)=.11, p=.896\right.$, partial $\left.\eta^{2}=.07\right]$, Teacher Gender $\left[F(1,1092)=1.83, p=.176\right.$, partial $\left.\eta^{2}=.27\right]$, and Student Gender $[F(1,1092)=$ $.18, p=.673$, partial $\left.\eta^{2}=.07\right]$ were not significant.

Student Responsibility. A three-way ANOVA was analyzed to examine the impact of Attractiveness Level, Teacher Gender, and Student Gender on Student Responsibility ratings. The tests of assumptions found there were no outliers. The Shapiro-Wilk's test of normality were significant for all conditions $(p<.05)$. As noted earlier, the robustness of the three-way ANOVA allowed for the continued analysis. Levene's Test of Equality of Error Variances was not significant, $p=.138$, indicating that there was homogeneity of variances. 
The results of the three-way ANOVA indicated there was no statistically significant three-way interaction, $F(2,1092)=.14, p=.871$, partial $\eta^{2}=.07$. The mean student blameworthiness ratings for all conditions are reported in Table 15. There were no significant two-way interactions between Attractiveness Level and Teacher Gender $[F(2,1092)=.01, p=$ .993, partial $\left.\eta^{2}=.05\right]$, Attractiveness Level and Student Gender $[F(2,1092)=1.25, p=.287$, partial $\left.\eta^{2}=.27\right]$, and Teacher Gender and Student Gender, $\left[F(1,1092)=.14, p=.710\right.$, partial $\eta^{2}$ $=.07]$. The main effects for Attractiveness Level $\left[F(2,1092)=.28, p=.754\right.$, partial $\left.\eta^{2}=.10\right]$, Teacher Gender $\left[F(1,1092)=.76, p=.384\right.$, partial $\left.\eta^{2}=.14\right]$, and Student Gender $[F(1,1092)=$ $2.20, p=.138$, partial $\left.\eta^{2}=.32\right]$ were not significant.

Student Credibility. A three-way ANOVA was analyzed to examine the impact of Attractiveness Level, Teacher Gender, and Student Gender on Student Credibility ratings. The tests of assumptions found several outliers and the Shapiro-Wilk's test of normality were significant for 11 or 12 conditions $(p<.05)$. Levene's Test of Equality of Error Variances was not significant, $p=.091$, indicating that there was homogeneity of variances.

The results of the three-way ANOVA indicated there was no statistically significant three-way interaction, $F(2,1092)=.13, p=.877$, partial $\eta^{2}=.07$. The mean student credibility ratings for all conditions are reported in Table 16. There were no significant two-way interactions between Attractiveness Level and Teacher Gender $[F(2,1092)=1.47, p=.230$, partial $\left.\eta^{2}=.32\right]$, Attractiveness Level and Student Gender $\left[F(2,1092)=.10, p=.354\right.$, partial $\eta^{2}$ $=.23]$, and Teacher Gender and Student Gender, $\left[F(1,1092)=1.78, p=.182\right.$, partial $\left.\eta^{2}=.27\right]$. The main effect for Teacher Gender was significant, $F(1,1092)=6.29, p=.012$, partial $\eta^{2}=.71$, with higher Student Credibility ratings for the male teacher compared to female teacher. The 
main effects for Level of Attractiveness $\left[F(2,1092)=1.13, p=.324\right.$, partial $\left.\eta^{2}=.25\right]$ and Student Gender $\left[F(1,1092)=.10, p=.749\right.$, partial $\left.\eta^{2}=.06\right]$ were not significant.

Student Empathy. A three-way ANOVA was analyzed to examine the impact of Attractiveness Level, Teacher Gender, and Student Gender on Student Empathy ratings. The tests of assumptions found there were no outliers. The Shapiro-Wilk's test of normality were significant for all conditions $(p<.05)$. Levene's Test of Equality of Error Variances was not significant, $p=.269$, indicating that there was homogeneity of variances.

The results of the three-way ANOVA indicated there was no statistically significant three-way interaction, $F(2,1092)=1.60, p=.203$, partial $\eta^{2}=.34$. The mean student empathy ratings for all conditions are reported in Table 17. There was a significant two-way interaction between Teacher Gender and Student Gender, $\left[F(1,1092)=4.11, p=.043\right.$, partial $\left.\eta^{2}=.53\right]$. The simple main effect of Teacher Gender on mean Student Empathy ratings was statistically significant for the male student $\left[F(1,1092)=4.11, p=.043\right.$, partial $\left.\eta^{2}=.53\right]$, but not for the female student, $F(1,1092)=.73, p=.393$, partial $\eta^{2}=.14$. Pairwise comparisons were made for the male student with a Bonferroni Adjustment. The Student Empathy ratings for the female teacher were significantly higher than the male teacher (See Figure 3). The simple main effect of Student Gender on mean Student Empathy ratings was not statistically significant for the male teacher $\left[F(1,1092)=1.93, p=.166\right.$, partial $\left.\eta^{2}=.28\right]$ or the female teacher $[F(1,1092)=2.18, p$ $=.140$, partial $\left.\eta^{2}=.32\right]$. See Figure 3 .

There were no significant two-way interactions between Attractiveness Level and Teacher Gender $\left[F(2,1092)=.63, p=.530\right.$, partial $\left.\eta^{2}=.16\right]$ and Attractiveness Level and Student Gender $\left[F(2,1092)=.88, p=.416\right.$, partial $\left.\eta^{2}=.20\right]$. The main effects for Attractiveness Level $\left[F(2,1092)=.21, p=.808\right.$, partial $\left.\eta^{2}=.08\right]$, Teacher Gender $[F(1,1092)=.64, p=.423$, 
partial $\left.\eta^{2}=.13\right]$, and Student Gender $\left[F(1,1092)=.01, p=.910\right.$, partial $\left.\eta^{2}=.05\right]$ were not significant.

Given that female participants assigned more guilt overall (as measured by more guilty votes and higher extent of guilt ratings) compared to males, an exploratory analysis regarding whether there were differences in student empathy ratings as a function of Participant Gender was conducted (males and females only, "other" was excluded due to low sample size). An independent samples t-test resulted in a significant effect $[t(1097)=-2.0, p=.028]$, with females having higher student empathy $(M=15.07, S D=8.44)$ than males $(M=13.98, S D=7.87)$. 


\section{CHAPTER 4}

\section{DISCUSSION}

This study examined the impact of the physical attractiveness and gender of the teacher, as well as the gender of the student, on juror decision-making in a sexual assault case involving a teacher and student. Specifically, the study explored the influence of the aforementioned variables on guilt determinations, sentencing decisions, perceptions of the teacher, and perceptions of the student. Overall, findings revealed while the gender of the teacher may impact juror decision-making, the level of attractiveness of the teacher and gender of the student had minimal effects.

\section{Guilt Determinations}

Based upon the What is Beautiful is Good (Dion et al., 1972) and Attractiveness Leniency Bias (e.g., Abel \& Waters, 2005; Stewart, 1980; 1985) theories, it was hypothesized that the attractive defendants would be rated as less guilty compared to the unattractive defendants. Contrary to expectation, no effect for level of physical attractiveness of the teacher on the likelihood of a participant voting guilty was found. Additionally, the attractiveness of the teacher did not influence ratings of the extent of guilt and belief that a sexual offense was committed. This finding is in line with prior studies that have not found an Attractiveness Leniency bias for guilt decisions in a sexual offense (e.g., Austin et al., 2013; Ahola et al., 2009). While some studies have shown this Attractiveness Leniency bias for judgements of culpability (e.g., Abwender \& Hough, 2001; Kerr, 1978; Kulka \& Kessler, 1978; Wilson \& Donnerstein, 1977), the present study provided an updated analysis of the impact that attractiveness may have on jurors using a methodologically sound design (e.g., large sample size, extensive pilot testing, inclusion of a control condition, issues with the manipulation of attractiveness). The present 
study also included numerous variables that could impact findings (e.g., participant, defendant, and victim gender) to comprehensively explore the Attractiveness Leniency bias, with results showing the gender variables do not seem to interact with attractiveness level to influence participants' guilt decisions. The present study found that despite participants recognizing the attractiveness of the defendant (as demonstrated in the manipulation check), characteristics of physical attractiveness did not impact decisions of guilt. This supports the notion that jurors may be able to remain objective in the face of varying levels of physical attractiveness when tasked with making important legal decisions.

Additionally, it was predicted the female defendant would be more likely to be acquitted and participants would rate them as less guilty compared to the male defendant. The results indicated that the female teacher was rated as less guilty and there was less of belief that a sex offense had been committed compared to the male defendant. That is, there is evidence that the gender of the defendant in a student/teacher sexual assault case may bias jurors' judgments of guilt. This is consistent with prior literature that has found increased guilt for male defendants compared to females in student/teacher sexual assault cases (e.g., Howell et al., 2011). Importantly, however, while a male defendant was viewed as guiltier and more likely to have committed the offense on the continuous guilt variables, this did not ultimately lead jurors to provide a guilty verdict in the end. There was no significant difference between participants voting guilty for the male defendant (14.4\%) compared to the female defendant (11.2\%). Therefore, jurors may possess gender biases toward defendants in these cases, though these biases did not seep into the ultimate decision on whether a defendant is guilty or not guilty. Thus, based on the evidence from the present study, attorneys and judges may not need be ultimately concerned that the gender of the defendant will result in a certain verdict. In the present study, however, jurors did not deliberate 
before reaching a verdict. Therefore, it may be that the deliberation process could potentially sway jurors' initial beliefs toward guilt or innocence. Thus, it is clear that more evidence is needed to further examine whether higher extent of guilt ratings and stronger belief a sex offense was committed by a male defendant would actually translate to more guilty verdicts in a realworld setting.

Another interesting finding was that participants were more confident in their verdict decisions in cases of female defendants compared to males. Given that the majority of verdicts were for not guilty, additional analyses were conducted for each verdict decision. Results showed that confidence ratings did not differ for guilty verdicts; however, participants were more confident in their not guilty verdicts when the defendant was female compared to male. This is consistent with the findings related to female teachers in this study being viewed as less guilty and less likely to have committed a sexual offense. It appears participants were likely more confident in their not guilty verdicts because they were less likely to believe the female was indeed guilty. This is in line with findings related to confidence in verdict in previous research on child sexual abuse conducted by Quas and colleagues (2002), which showed participants were more confident about a male defendant's guilt compared to a female's. Taken together, it appears that individuals may be more confident in not guilty verdicts for a female defendant and more confident in guilty verdicts for a male defendant in cases of student/teacher sexual assault.

Contrary to expectations, results did not support the hypothesis that cases with a female victim would receive more guilty verdicts and higher extent of guilt ratings than cases involving a male victim. Rather, there was no effect for the gender of the student on decisions related to guilt. This suggests that if jurors do hold any biases related to a 'typical victim' in a student/teacher sexual assault case, it may not affect their decision of guilt in the case. Prior 
research has found interactions between victim gender and other variables, such as defendant and participant gender (Quas et al., 2002; Rogers \& Davies, 2007). However, the present study did not find any support for the interaction of these variables related to guilt decisions. It may be that the increased media attention to cases of sexual assault has raised awareness that both males and females can be victims. It is encouraging that the gender of the victim does not influence jurors' ultimate decisions, as research has shown that male victims are fairly common (i.e., 5-17\% of males are sexually abused during childhood; Briere \& Eliott, 2003; Douglas \& Finkelhor, 2005; Finkelhor, 1994) and they experience negative consequences as a result of the abuse (e.g., Davies \& Rogers, 2006).

Exploratory analyses were conducted to determine whether the gender of the participant influenced verdict decisions and extent of guilt ratings. It was found that female participants had higher odds of voting guilty and had higher extent of guilt ratings compared to male participants. This is consistent with a prior meta-analysis that found that females are more conviction-prone in rape and child sexual abuse cases than males (Schutte \& Hosch, 1997), as well studies of nonsexual offenses (e.g. elder physical abuse; Kinstle, Hodell, \& Golding, 2008) and non-crimespecific analyses (Devine \& Caughlin, 2014). In a study by Bottoms and colleagues (2014), female participants had more empathy for the victim, were more opposed to sexual acts between an adult and child, believed children more in general, and were more "pro-women," which helped explain the gender differences in guilt decisions in a child sexual abuse case. While this study did not test for most of the variables in the Bottoms et al. (2014) study, the data on student empathy were consistent with their findings, in that female participants were more empathetic toward the victim compared to males. This increased empathy may help explain why the females were more conviction-prone than males in a case of student/teacher sexual assault. In sum, the 
results showed that female participants, regardless of the defendant gender, may be more punitive in cases of student/teacher sexual assault. This information may be important in jury selection in student/teacher sexual assault cases, in that the mere gender of the juror may impact guilt determinations.

\section{Sentencing Decisions}

It was predicted that the attractive defendants would receive more lenient sentencing decisions than unattractive defendants. Results suggested that participants' sentencing decisions, predicted likelihood of reoffending, and recommendations for sex offender laws (e.g., sex offender registration, community notification) were not impacted by the level of attractiveness of the defendant. These findings are similar to prior studies that have not found an influence of sentencing for varying levels of physical attractiveness (e.g., Ahola et al., 2009; Austin et al., 2013). However, it contradicts some studies that have shown an effect of attractiveness on sentencing (Erian et al., 1998; Jacobson, 1981; Jacobson \& Popovich, 1983). As noted earlier in relation to guilt determinations, these differing findings may be due to a wide variety of methodological differences, such as content and type of case (i.e., student/teacher sexual assault cases versus other types of crimes), manipulation of attractiveness (e.g., use of photographs versus a description, procedure to select photographs), and research design (e.g., sample size, use of a control condition, inclusion of gender variables). Overall, these findings suggest that regardless of the physical attractiveness of a teacher in a student/teacher sexual assault case, jurors' punitiveness in terms of sentencing decisions is unaffected. However, it should be noted that in the real-world court situation, judges are tasked with the ultimate decisions related to sentencing. While these findings show juror's may be immune to the impact of physical attractiveness on sentencing suggestions, future studies could examine judges decisions in an 
experimental study, as the field studies have suggested there may be bias in sentencing by judges based on attractiveness (Stewart, 1980; 1985).

One interesting finding was that participants were more likely to recommend sex offender-specific treatment when there was no photograph presented compared to both attractive and unattractive photographs. It may be that seeing a photograph humanizes the defendant for the jurors, leading them to not feel as though the person is in significant need of rehabilitation. When the jurors do not see the defendant's appearance, they may have their own image of stereotypical sex offender which leads them to believe the person requires treatment. Future studies could examine whether viewing a photograph of a sex offender versus not viewing has an impact on individuals' beliefs about the need for, and likelihood of success of, rehabilitation. In general, sex offenders tend to be a vilified group, and it may be beneficial to humanize this group of offenders by allowing people to see images of the people who commit such crimes, in hopes of increasing support for rehabilitation given the research base to show treatment can be effective (e.g., Kim, Benekos, \& Merlo, 2016)

There were no significant findings on the various sentencing variables for the gender of the teacher and gender of the student. This contradicts some prior studies showing that gender of the defendant has an impact on the sentence length they are given (e.g., Mazzella \& Feingold, 1994; Rodriguez et al., 2006). However, the findings are consistent with a prior study on student/teacher sexual assault, which did not find an effect for teacher gender on length of sentence or whether the person should have to register. Future research may want to continue to explore the influence of defendant gender in student/teacher sexual assault cases, given that these cases may be different than other sexual assault cases against a minor as demonstrated by the varied findings across the research. Moreover, additional research may be warranted to provide 
empirical support for or against the anecdotal evidence of female teachers receiving shorter sentences (e.g., Mary Kay Letourneau). The null findings related to the influence of student gender on sentencing is in line with studies finding that gender of the victim has no influence on jurors' sentencing recommendations (Patrick \& Marsh, 2011). Taken all together, it is a positive findings that gender variables may be not influencing jurors' beliefs about the extent of punishment in the present study, as gender biases should not have an impact on whether a person receives a more lenient or harsh punishment.

\section{Perceptions of the Teacher}

The results found an interaction between attractiveness level and teacher gender on ratings of teacher credibility (i.e., the extent to which the teacher's view was trusted and believed). Specifically, it was found that when there was no photograph, the female teacher receives higher ratings of credibility compared to the male. This is further supported by a significant main effect (regardless of attractiveness condition) for teacher gender on teacher credibility, in that females teachers were overall viewed as more credible compared to the male teachers. These findings are consistent with other results in this study that in general, the females are found to be treated more leniently (regardless of attractiveness level) and, thus, may be viewed as more credible. Moreover, it was found that when the teacher is female, the no photo condition received higher ratings of credibility compared to the unattractive teacher. This suggests that the unattractive defendant may be seen as less credible in cases that a female teacher is on trial. This finding was the only significant result showing differences between conditions of attractiveness across the entire study. Thus, while the results may show the unattractive female appeared to be viewed as less credible than no photo at all, the finding should 
be taken lightly given the body of evidence garnered throughout the study that did not find support for attractiveness level influencing jurors' decisions and perceptions.

There was also a significant interaction between teacher gender and student gender on the teacher responsibility ratings (i.e., the extent to which the defendant was at fault). It was found that when the student was female, participants ascribed higher teacher responsibility ratings to the male teacher compared to the female teacher. Also, when the teacher was female, participants ascribed high teacher responsibility ratings when the student was male versus female. Taken together, these findings suggest that jurors may view the teacher accused of sexual assault against a student as more responsible in cases of opposite sex victims. That is, the male teacher was deemed more responsible when the victim was female, and the female teacher was deemed more responsible when the victim was male. A study by Plumm et al. (2013) found that while same-gendered student/teacher sexual assault cases were deemed as more likely to have been committed, the victim blame was highest in instances in cases of opposite gendered offenses, with highest blame for the male victim and a female teacher. Taken together, it may be that both the teacher and student are held more responsible in cases of opposite-sex combinations. This may be indicative of some perpetuated gender biases, in that a defendant is held to be more responsible for their acts when the victim is a member of the opposite sex given this fits a traditional sexual script (Denov, 2003). Moreover, research has shown that in cases of male perpetrators of sexual assault, the victims are predominately female, whereas female perpetrators offend against both males and females equally (McCloskey \& Raphael, 2005). Thus, the participants in this study were holding male defendants more responsible in instances where the gender combination is more likely. However, for the female defendant, their gender assumptions that were possibly made were not in line with prior research, suggesting increased education on 
gender combinations of offending may be valuable. The public may benefit from leaning about the prevalence of male and female sex offenders, with emphasis on the fact that both genders of offenders can have victims of the same or opposite sex. It should also be noted that there was also a main effect for gender on ratings of teacher responsibility, with the male teacher being held more responsible than the female. This finding further supports the aforementioned results suggesting that the male teachers appear to be perceived as more culpable for the crime for which they were accused.

There was no effect for attractiveness level, teacher gender, or student gender on ratings of empathy for the teacher. The mean empathy ratings were toward the lower end of the scale (i.e., 14.53 on a scale of 3-30), suggesting that participants did not experience high levels of empathy for the teacher. Surprisingly, this mirrored the empathy scores of the student as well (i.e., mean 14.58 on a scale of 3-30), suggesting that participants do not experience much empathy toward either party in student/teacher sexual assault case. This may be due to societal portrayals of student/teacher sexual relationships as being consensual in many instances (e.g., movies, television shows, music, pornography), which could lead people to not feel the sexual interactions were sexual abuse. In fact this study had an overall majority of not guilty verdicts (74.4\%), which could further reflect jurors' perceptions of student/teacher sexual offenses. Seeing as jurors are asked to be objective when judging court cases, it may be a positive finding that there are not extreme levels of empathy in either direction. In fact, past research has shown that when jurors were asked to take the perspective of a defendant in a child sexual assault case, they had more empathy for the perpetrator, than those who are not given the same instruction, and that this resulted in lower guilt ratings (Haegerich \& Bottoms, 2000). Therefore, the findings 
of the present study are encouraging, given that high levels of empathy have the potential to color jurors' perspectives and sway their determinations of guilt.

\section{Perceptions of the Student}

Results indicated there were no significant findings related to the amount of blame and responsibility attributed to the student. That suggests that jurors were not biased by the physical attractiveness or gender of the defendant, nor the gender of the student, when judging blameworthiness and responsibility of the alleged victim. Moreover, overall, the ratings of blameworthiness $(M=16.77$ on a scale of 6-60) and responsibility $(M=14.62$ on scale of 3-30) of the student were low. This is encouraging, as more victims of abuse may be empowered to come forward if they feel they will not be blamed or viewed as partially responsible for the abuse. This could also be helpful to survivors of abuse who are coping with the court process, as it may allow victims to feel supported in an adversarial process.

It was hypothesized that there would be higher levels of victim empathy for the female student compared to the male student. Conversely, this study found that participants had higher student empathy ratings when the teacher was female compared to male, but only for the male victim. This finding was especially surprising, as it might be expected that the least amount of empathy would be found in cases of the female teacher and male student, as this has been stereotyped to be every young male's "fantasy" (Dvorak, 2014). This may be due to participants having a stereotypical male sex offender in their minds, making the female defendant illicit a stronger emotional reaction and more feelings for the victim. Moreover, media attention in cases of a female offending against a student may have an impact on the salience of these types of cases and lead to increased ability for participants to take the perspective of the male victim. As a whole, seeing high levels of empathy for the male victim in this study may reflect that people do 
recognize that males in these cases are indeed victims, which is contrary to the stereotype of the young man's "fantasy" and the attractive female teacher (Larosa, 2014).

In regards to perceived student credibility, results indicated that participants believed the student was more credible in instances where the defendant was male. This may be reflective of participants believing a victim in a case with a male perpetrator as more likely, given that males tend to commit the vast majority of sexual offenses (e.g., The National Center for Victims of Crime, n.d.). It is not shocking that a juror may be more apt to believe the student's report in a case of student/teacher sexual assault when the alleged perpetrator is male. However, there are female child sexual abusers in $14 \%$ of cases with male victims and $6 \%$ of cases with female victims. Moreover, there is evidence to show an even higher percentage of female offenders are involved in student/teacher sexual offenses, with $43 \%$ of perpetrators being females (American Association of University Women, 2001). Therefore, as noted earlier, increased education of the community on sexual offenders may be beneficial, especially regarding the possibility that a female can commit a sexual offense.

\section{Limitations}

There are several limitations of the present study that that are worth noting. The case was presented as a one-page vignette. This decision was done to be in line with prior studies (i.e., Austin et al., 2013), but also with the idea that presenting participants with a vague and abbreviated case would allow for any biases related to physical attractiveness or gender to be revealed. In fact, some researchers cautioned against using vignettes that are too long (Anderson \& Lyons, 2005) and recommend they are vague enough to "force" individuals to use additional processes when making conclusions about the vignette (Barter \& Reynold, 1999). However, it may be beneficial for future studies to examine this topic using a more detailed trial transcript or 
a video presentation of a case, in order to provide a more accurate depiction of a case in a realworld court scenario.

Furthermore, the sample used in this study is from an online domain, Mechanical Turk. Given the study is completed online for monetary value, it may be possible that some respondents were not attending properly to content (e.g., not reading questions thoroughly, randomly responding). In an effort to counter this, manipulation check questions were included and used to remove any data sets containing incorrect answers to these questions. However, there is always a chance that people attended to some questions and not others, which has the potential to alter the results. Another potential downfall of the sample used is the individuals on Mechanical Turk are volunteering to complete surveys/tasks online for monetary value and, therefore, may not be fully representative of the general population.

This study also used photographs of White individuals who were approximately 21-30 years old. That being said, there is prior research showing that race/ethnicity and age of a defendant may have an influence on juror decision-making (e.g., Mitchell, Haw, Pfeifer, \& Meissner, 2005; Pozzulo et al., 2010). Thus, future research could explore the interactions of additional variables, such as race/ethnicity and age, on a student/teacher sexual assault case. Moreover, the student in the case used for this study was 13 years old. It may be beneficial to have continued research on how victims in student/teacher sexual assault cases are viewed depending on their age, as a 10 year old victim may be perceived differently than a 16 year old victim.

\section{Conclusions}

Overall, the results of the present study produced five major conclusions. First, the study did not find strong support for an Attractiveness Leniency bias in guilt determinations, 
sentencing decisions, or perceptions of the defendant and alleged victim. The only significant finding related to attractiveness was that female defendants were seen as less credible when they were unattractive compared to no photo at all; however, this bias was not reflected in any other finding. Thus, it appears that overall, although jurors may recognize the level of attractiveness of the defendant, it does not appear to create a bias in decision-making. Second, results found the female defendant in a student/teacher sexual assault case was believed to be less guilty, less likely to have committed the sexual offense, and more credible than their male counterpart. Moreover, for the female defendant, the participants believed the alleged victim was less credible and they were more confident in their not guilty verdicts compared to the male defendant. However, these beliefs did not translate into differences in verdicts between males and females. That is, female defendants in these cases may be viewed as less culpable, though the ultimate decisions of guilt may not reflect these biases. Third, in some instances, the perceptions of the teacher and student were influenced by an interaction between the teacher's gender and student's gender. Notably, teachers were held more responsible in instances when the case involved a victim of the opposite sex. This may reflect a lack of understanding that same-sex offenses are possible and should not automatically result in decreased responsibly for the defendant. Fourth, the gender of the victim had no influence on jurors' decisions of guilt or sentencing. This may be reflective of a greater understanding by the community that males and females can both be victims of child sexual abuse. Fifth, although not a primary focus of the present study, there appears to be effects of participant gender on decision-making in this educator misconduct case. Specifically, female mock jurors were more likely to provide a guilty verdict and higher extent of guilt ratings than the male jurors. Thus, as with prior research, it appears that females tend to hold defendants more culpable in alleged sexual offense cases, including those involving a 
student and teacher. Taken together, the present study sheds light on how the attractiveness and gender of the defendant, as well as the gender of the student, influence jurors' decisions in a student/teacher sexual assault case.

\section{Broader Implications}

Conclusions made from the current study may have broad implications for the criminal justice system, mental health professionals, and the community at large. Professionals in the court system, such as attorneys and judges, may benefit from information garnered from the study. While the results indicate physical attractiveness of a defendant or the gender of a victim were not significant, it may be worth taking into consideration the impact the gender of the defendant and gender of the juror has on decision-making in a student/teacher sexual assault case. That is, it appears that male defendants in student/teacher sexual assault cases may be viewed as more culpable and female jurors tend to be more conviction-prone than males. While the results of the present study support this notion, further research is much needed. Not only would it be beneficial to replicate these findings, but also expand on this study using an actual jury deliberation or incorporating additional variables could shed more light on how these types of cases are treated in the criminal justice system.

In regards to clinical implications, mental health professionals working with individuals who have been victimized by an educator may benefit from some of these findings. The findings suggest a victim may be viewed as less credible if the defendant is female, which could be harmful to a victim going through the process of testifying. Preparing the victim so that they feel as comfortable and confident as possible may help the individual through the difficult process. Moreover, given the cultural prevalence of the female teacher/male student "fantasy", male victims in these case may be validated knowing that people appear to have high levels of 
empathy for male victims when the teacher is female. Additionally, in general, the study found that victims were not ascribed high levels of blame or responsibility, which may be comforting for a victim to know when faced with the stress of the court process.

In regards to treating an offender involved in a student/teacher sexual assault case, treatment providers may benefit from recognizing and incorporating gender differences into treatment. Since female offenders were seen as more credible and the victims were discredited more, female perpetrators may be more apt to deny, minimize, or justify the behavior if those around them are also treating those situations more leniently. According to the Risk-NeedsResponsivity Model (RNR; Bonta \& Andrews, 2007), sex offender treatment should focus on each individual offender's level of risk, criminogenic needs, and responsivity factors in an attempt to reduce recidivism. This model stresses the importance of considering factors such as gender for offenders in student/teacher sexual assault cases, in order to provide the most individualized treatment for the offender. In the case of female teachers who offend, treatment providers may want to be aware of these potential cognitive distortions related to their offending, given the offender may have these reinforced by societal stereotypes. Even though the offense committed by a female and male defendant may be similar, the treatment should be based on the individualized needs of the offender, including how gender may factor into the offending behaviors. Additional clinical research could potentially help shed light on the "teacher/lover" typology of female sex offenders so that treatment can best fit the person's needs.

Lastly, community education may be an important next step, in that the general population should be better informed regarding student/teacher sexual assault cases. The community could benefit from knowing more about the prevalence of these cases, as well as how gender stereotypes may influence people's perceptions of these crimes. Additionally, it is 
possible that this increased education may help prevent instances of student/teacher sexual assault, in that a better understanding that the offenses can be same-gender or opposite-gender can increase awareness to any unusual or concerning behaviors between a teacher and their student. With cases of student/teacher sexual assault permeating the media, there is much need for continued research in this area and to better inform criminal justice professionals, treatment providers, and community members about this unique type of sexual offense. 


\section{Appendix A}

Photographs

\begin{tabular}{ll}
\hline Attractive Male & Mean \\
\hline Attractiveness & 3.99 \\
Facial Expression & .68 \\
Age & 1.93 \\
\hline Unattractive Male & Mean \\
\hline Attractiveness & 1.97 \\
Facial Expression & -.94 \\
Age & 2.49 \\
\hline
\end{tabular}

\begin{tabular}{lc}
\hline Attractive Female & Mean \\
\hline Attractiveness & 3.88 \\
Facial Expression & -.38 \\
Age & 2.13 \\
\hline
\end{tabular}

\begin{tabular}{lc}
\hline Unattractive Female & Mean \\
\hline Attractiveness & 2.03 \\
Facial Expression & -.72 \\
Age & 2.32 \\
\hline
\end{tabular}




\section{Appendix B}

\section{Pilot Vignette}

A 35-year-old high school teacher was charged last week with sexual misconduct with a minor for allegedly having sexual contact with a 14-year-old student. Amity police received a complaint on May 15 that Amity High School teacher Michael/Michelle Smith was involved in a sexual relationship with a female/male student.

Detectives spoke with the alleged victim, who said Smith had been her/his math teacher during the 2013-2014 school year. The girl/boy said Smith began sending her/him sexually explicit emails in March according to court documents. The student then alleged that she/he would go for coffee with Smith and when he/she drove the student home they would engage in sexual acts in Smith's car.

According to police, Smith stated he/she met with the student for tutoring sessions at the coffee shop since the student missed a week of school and required extra tutoring and he/she thought the coffee shop would be more comfortable than the classroom. A witness reportedly saw the pair parked in a car in front of the student's home. The witness also reported they saw the student exit the car and the student did not seem distressed.

Detectives contacted Smith at the school on May 15. He/She agreed to speak with police and has allowed the police full access to his/her electronic accounts. Michael/Michelle indicated that the student was upset with him/her because despite the tutoring sessions, she/he did poorly in the class. Following an investigation, police were unable to find any evidence of the email communication. 


\section{Appendix C}

\section{Final Vignette}

A 35-year-old high school teacher was charged last week with sexual misconduct with a minor for allegedly having sexual contact with a 13-year-old student. Amity police received a complaint on May 15 that Amity High School teacher Michael/Michelle Smith was involved in a sexual relationship with a female/male student.

Detectives spoke with the alleged victim, who said Smith had been her/his math teacher during the 2013-2014 school year. The girl/boy said Smith began sending her/him sexually explicit emails in March according to court documents. The student then alleged that she/he would go for coffee with Smith and when he/she drove the student home they would engage in sexual acts in Smith's car. According to one of the student's teachers, he/she has recently appeared distressed in school and his/her grades have been declining. The student denied any current problems when asked by the teacher.

According to police, Smith stated he/she met with the student for tutoring sessions at the coffee shop since the student missed a week of school and required extra tutoring and he/she thought the coffee shop would be more comfortable than the classroom. A witness reportedly saw the pair parked in a car in front of the student's home. The witness also reported they saw the student exit the car and the student did not seem distressed.

Detectives contacted Smith at the school on May 15. He/She agreed to speak with police and has allowed the police full access to his/her electronic accounts. Michael/Michelle indicated that the student was upset with him/her because despite the tutoring sessions, she/he did poorly in the class. Following an investigation, police were unable to find any evidence of the email communication. 


\section{Appendix D}

Questions Following the Vignette

1. (Manipulation check) What is the defendant's gender? Male/Female

2. (Manipulation check) What is the student's gender? Male/Female

3. (Manipulation check) What is the defendant being accused of? Statutory rape, Burglary, Drug Possession

4. I would find the defendant: Guilty/Not Guilty

5. Please rate the extent to which you would find the defendant guilty. (1=not at all, $10=$ completely)

6. How confident are your verdict? (1=not at all confident, $10=$ very confident $)$

7. Rate the extent to which you believe a sex offense was committed. (1=strongly do not believe, $10=$ strongly do believe)

8. I believe the sentence length should be: No time spent incarcerated, less than one year, 1 5 years, 6-10 years, 11-15 years, 16-20 years, 21-25 years, 25 years or more.

9. I believe the likelihood the defendant would commit the same crime again is: $(1=$ very unlikely, $10=$ very likely)

10. I believe the defendant should have to register as a sex offender (i.e., online registry of information about sex offenders living in their communities). (1=strongly disagree, $10=$ strongly agree $)$

11. I believe the sentence defendant should have to register as a sex offender for: No, should not have to register, 15 years, 25 years, For life

12. I believe the defendant should be mandated to sex offender treatment. (1=strongly disagree, 10=strongly agree) 
13. I believe the defendant should be subject to community notification (i.e., law enforcement agency where the offender currently resides, can, if it chooses, release information on sex offenders residing in the community). (1=strongly disagree, $10=$ strongly agree $)$

14. Please answer the following: (1=strongly disagree to $10=$ strongly agree $)$

a. The student is to blame for the actions of the teacher

b. The student should know to be more careful with interactions with certain teachers

c. The student should have known better than to engage in such behaviors

d. The teacher's actions were a result of unwanted attention from the student

e. The teacher was provoked

f. The teacher's actions were justified

15. To what extent did the defendant act carelessly? (1=not at all, 10=completely)

16. To what extent is the defendant to blame for what happened? $(1=$ not at all, $10=$ completely)

17. To what extent is the defendant responsible for what happened? (1=not at all, $10=$ completely)

18. To what extent did the student act carelessly? (1=not at all, 10=completely)

19. To what extent is the student to blame for what happened? (1=not at all, $10=$ completely)

20. To what extent is the student responsible for what happened? (1=not at all, $10=$ completely)

21. Please answer the following: (1=strongly disagree to $10=$ strongly agree $)$

a. I can imagine the thoughts running through the defendant's head 
b. I can feel the same feelings the defendant experiences

c. I can take the perspective of the defendant

22. Please answer the following: (1=strongly disagree to $10=$ strongly agree $)$

a. I can imagine the thoughts running through the student's head

b. I can feel the same feelings the student experiences

c. I can take the perspective of the student

23. How honest is the defendant? (1=not at all, 10=completely $)$

24. How believable is the defendant? $(1=$ not at all, $10=$ completely $)$

25. How credible is the defendant? ( $1=$ not at all, $10=$ completely $)$

26. How likable is the defendant? ( $1=$ not at all, 10=completely)

27. How physically attractive is the defendant? $(1=$ not at all, $10=$ completely $)$

28. How honest is the victim? (1=not at all, 10=completely $)$

29. How believable is the victim? ( $1=$ not at all, $10=$ completely $)$

30. How credible is the victim? $(1=$ not at all, $10=$ completely $)$

31. How likable is the victim? ( $1=$ not at all, $10=$ completely $)$ 


\section{Appendix E}

\section{Demographics Questionnaire}

1. What is your gender? Male; Female

2. What is your race/ethnicity? Hispanic or Latino; Caucasian or White/Non-Hispanic; African-American or Black; Asian; Biracial (more than one race)

3. What is your age?

4. Have you ever been a victim of rape or sexual assault as a minor (under the age of 17)? 
Table 1

Mean guilt ratings as a function of Attractiveness Level and Teacher Gender.

\begin{tabular}{|c|c|c|c|c|c|c|}
\hline & Male & $M(S D)$ & Female & $M(S D)$ & Total & $M(S D)$ \\
\hline Attractive Photograph & & $2.88(2.70)$ & & $3.00(2.56)$ & & $2.94(2.59)$ \\
\hline Unattractive Photograph & & $4.41(3.36)$ & & $3.56(2.73)$ & & $4.05(3.10)$ \\
\hline No Photograph & & $4.00(3.62)$ & & $3.24(2.44)$ & & $3.67(3.14)$ \\
\hline Total & & $3.85(3.30)$ & & $3.25(2.54)$ & & \\
\hline
\end{tabular}


Table 2

Binomial Logistic Regression Predicting Likelihood of a Guilty Verdict based on Attractiveness Level, Teacher Gender, Student Gender, and Participant Gender.

\begin{tabular}{|c|c|c|c|c|c|c|c|c|c|}
\hline & \multirow[t]{2}{*}{$B$} & \multirow[t]{2}{*}{ S.E. } & \multirow[t]{2}{*}{ Wald } & \multirow[t]{2}{*}{$d f$} & \multicolumn{2}{|c|}{$p$} & \multirow[t]{2}{*}{$\begin{array}{l}\text { Odds } \\
\text { Ratio }\end{array}$} & \multicolumn{2}{|c|}{$\begin{array}{l}\text { 95\% C.I. for } \\
\text { Odds Ratio }\end{array}$} \\
\hline & & & & & & & & Lower & Upper \\
\hline $\begin{array}{l}\text { Attractiveness Level } \\
\text { (Unattractive) }\end{array}$ & .032 & .167 & .036 & & 1 & .850 & 1.032 & .744 & 1.432 \\
\hline $\begin{array}{l}\text { Attractiveness Level } \\
\text { (No Photo) }\end{array}$ & .040 & .175 & .052 & & 1 & .820 & 1.041 & .739 & 1.466 \\
\hline Teacher Gender & -.202 & .140 & 2.077 & & 1 & .150 & .817 & .621 & 1.075 \\
\hline Student Gender & -.113 & .140 & .650 & & 1 & .420 & .894 & .680 & 1.175 \\
\hline Participant Gender & .278 & .141 & 3.926 & & 1 & .048 & 1.321 & 1.003 & 1.740 \\
\hline Constant & -1.104 & .173 & 40.498 & & 1 & .000 & .332 & & \\
\hline
\end{tabular}

Note: All gender variables are females compared to males. 
Table 3

Extent of Guilt Ratings as a Function of Attractiveness Level, Teacher Gender, and Student Gender.

\begin{tabular}{|c|c|c|c|c|c|}
\hline Attractiveness Level & Teacher Gender & Student Gender & Mean & $S D$ & $N$ \\
\hline \multirow[t]{9}{*}{ Attractive } & \multirow[t]{3}{*}{ Male } & Male & 4.90 & 2.99 & 90 \\
\hline & & Female & 4.64 & 2.76 & 107 \\
\hline & & Total & 4.76 & 2.86 & 197 \\
\hline & \multirow[t]{3}{*}{ Female } & Male & 4.86 & 3.07 & 85 \\
\hline & & Female & 4.52 & 3.10 & 88 \\
\hline & & Total & 4.69 & 3.08 & 173 \\
\hline & \multirow[t]{3}{*}{ Total } & Male & 4.88 & 3.02 & 175 \\
\hline & & Female & 4.58 & 2.91 & 195 \\
\hline & & Total & 4.72 & 2.96 & 370 \\
\hline \multirow[t]{9}{*}{ Unattractive } & \multirow[t]{3}{*}{ Male } & Male & 4.77 & 3.01 & 102 \\
\hline & & Female & 4.77 & 2.82 & 120 \\
\hline & & Total & 4.77 & 2.91 & 222 \\
\hline & \multirow[t]{3}{*}{ Female } & Male & 4.24 & 2.84 & 91 \\
\hline & & Female & 4.16 & 2.89 & 86 \\
\hline & & Total & 4.20 & 2.86 & 177 \\
\hline & \multirow[t]{3}{*}{ Total } & Male & 4.52 & 2.94 & 193 \\
\hline & & Female & 4.51 & 2.86 & 206 \\
\hline & & Total & 4.52 & 2.89 & 399 \\
\hline \multirow[t]{9}{*}{ No Photo } & \multirow[t]{3}{*}{ Male } & Male & 5.34 & 2.87 & 89 \\
\hline & & Female & 5.41 & 3.17 & 74 \\
\hline & & Total & 5.37 & 3.00 & 163 \\
\hline & \multirow[t]{3}{*}{ Female } & Male & 4.89 & 3.00 & 101 \\
\hline & & Female & 3.72 & 3.01 & 71 \\
\hline & & Total & 4.41 & 3.05 & 172 \\
\hline & \multirow[t]{3}{*}{ Total } & Male & 5.10 & 2.94 & 190 \\
\hline & & Female & 4.58 & 3.19 & 145 \\
\hline & & Total & 4.87 & 3.06 & 335 \\
\hline \multirow[t]{9}{*}{ Total } & \multirow[t]{3}{*}{ Male } & Male & 4.99 & 2.96 & 281 \\
\hline & & Female & 4.88 & 2.90 & 301 \\
\hline & & Total & $4.93 *$ & $2.92 *$ & 582 \\
\hline & \multirow[t]{3}{*}{ Female } & Male & 4.67 & 2.98 & 277 \\
\hline & & Female & 4.16 & 3.00 & 245 \\
\hline & & Total & $4.43^{*}$ & $3.00 *$ & 522 \\
\hline & \multirow[t]{3}{*}{ Total } & Male & 4.83 & 2.97 & 558 \\
\hline & & Female & 4.56 & 2.96 & 546 \\
\hline & & Total & 4.70 & 2.97 & 1104 \\
\hline
\end{tabular}

Note: An asterisk (*) indicates the means and standard deviations involved in the significant main effect for Teacher Gender. 
Table 4

Extent of Guilt Ratings as a Function of Attractiveness Level, Teacher Gender, and Participant Gender.

\begin{tabular}{|c|c|c|c|c|c|}
\hline Attractiveness Level & Teacher Gender & Participant Gender & Mean & $S D$ & $N$ \\
\hline \multirow[t]{11}{*}{ Attractive } & \multirow[t]{3}{*}{ Male } & Male & 4.46 & 2.90 & 87 \\
\hline & & Female & 4.99 & 2.82 & 110 \\
\hline & & Total & 4.76 & 2.86 & 197 \\
\hline & \multirow[t]{4}{*}{ Female } & Male & 4.13 & 3.08 & 77 \\
\hline & & Female & 5.11 & 3.06 & 93 \\
\hline & & Other & 6.00 & 1.73 & 3 \\
\hline & & Total & 4.69 & 3.08 & 173 \\
\hline & \multirow[t]{4}{*}{ Total } & Male & 4.30 & 2.98 & 164 \\
\hline & & Female & 5.04 & 2.92 & 203 \\
\hline & & Other & 6.00 & 1.73 & 3 \\
\hline & & Total & 4.72 & 2.96 & 370 \\
\hline \multirow[t]{11}{*}{ Unattractive } & \multirow[t]{4}{*}{ Male } & Male & 4.62 & 2.99 & 100 \\
\hline & & Female & 4.85 & 2.82 & 121 \\
\hline & & Other & 10.00 & & 1 \\
\hline & & Total & 4.77 & 2.91 & 222 \\
\hline & \multirow[t]{3}{*}{ Female } & Male & 3.81 & 2.82 & 88 \\
\hline & & Female & 4.60 & 2.86 & 89 \\
\hline & & Total & 4.20 & 2.86 & 177 \\
\hline & \multirow[t]{4}{*}{ Total } & Male & 4.24 & 2.93 & 188 \\
\hline & & Female & 4.74 & 2.83 & 210 \\
\hline & & Other & 10.00 & & 1 \\
\hline & & Total & 4.52 & 2.89 & 399 \\
\hline \multirow[t]{11}{*}{ No Photo } & \multirow[t]{3}{*}{ Male } & Male & 5.39 & 3.03 & 83 \\
\hline & & Female & 5.35 & 2.99 & 80 \\
\hline & & Total & 5.37 & 3.00 & 163 \\
\hline & \multirow[t]{4}{*}{ Female } & Male & 4.07 & 3.08 & 71 \\
\hline & & Female & 4.63 & 3.03 & 100 \\
\hline & & Other & 6.00 & & 1 \\
\hline & & Total & 4.41 & 3.05 & 172 \\
\hline & \multirow[t]{4}{*}{ Total } & Male & 4.78 & 3.11 & 154 \\
\hline & & Female & 4.95 & 3.03 & 180 \\
\hline & & Other & 6.00 & & 1 \\
\hline & & Total & 4.87 & 3.06 & 335 \\
\hline
\end{tabular}


Total

\begin{tabular}{rlrrr} 
& Female & 5.03 & 2.86 & 311 \\
& Other & 10.00 & & 1 \\
& Total & $4.93^{*}$ & $2.92^{*}$ & 582 \\
& Female & 3.99 & 2.97 & 236 \\
& Male & 4.78 & 2.99 & 282 \\
& Female & 6.00 & 1.41 & 4 \\
& Other & $4.43^{*}$ & $3.00^{*}$ & 522 \\
& Total & $4.42^{* *}$ & $3.01^{* *}$ & 506 \\
& Male & $4.91^{* *}$ & $2.92^{* *}$ & 593 \\
& Fotal & $6.80^{* *}$ & $2.17^{* *}$ & 5 \\
& Other & 4.70 & 2.97 & 1104 \\
\hline
\end{tabular}

Note: One asterisk indicates the means and standard deviations involved in the significant main effect for Teacher Gender. Two asterisks (**) and bold lettering indicates the means and standard deviations involved in the significant main effect for Participant Gender. 
Table 5

Confidence Ratings as a Function of Attractiveness Level, Teacher Gender, and Student Gender.

\begin{tabular}{|c|c|c|c|c|c|}
\hline Attractiveness Level & Teacher Gender & Student Gender & Mean & $S D$ & $N$ \\
\hline \multirow[t]{9}{*}{ Attractive } & \multirow[t]{3}{*}{ Male } & Male & 7.10 & 2.50 & 90 \\
\hline & & Female & 6.89 & 2.14 & 107 \\
\hline & & Total & 6.98 & 2.31 & 197 \\
\hline & \multirow[t]{3}{*}{ Female } & Male & 7.28 & 2.22 & 85 \\
\hline & & Female & 7.35 & 2.39 & 88 \\
\hline & & Total & 7.32 & 2.30 & 173 \\
\hline & \multirow[t]{3}{*}{ Total } & Male & 7.19 & 2.36 & 175 \\
\hline & & Female & 7.10 & 2.26 & 195 \\
\hline & & Total & 7.14 & 2.31 & 370 \\
\hline \multirow[t]{9}{*}{ Unattractive } & \multirow{3}{*}{ Male } & Male & 7.14 & 2.32 & 102 \\
\hline & & Female & 6.86 & 2.56 & 120 \\
\hline & & Total & 6.99 & 2.45 & 222 \\
\hline & \multirow[t]{3}{*}{ Female } & Male & 7.09 & 2.30 & 91 \\
\hline & & Female & 7.02 & 2.34 & 86 \\
\hline & & Total & 7.06 & 2.31 & 177 \\
\hline & \multirow[t]{3}{*}{ Total } & Male & 7.11 & 2.30 & 193 \\
\hline & & Female & 6.93 & 2.47 & 206 \\
\hline & & Total & 7.02 & 2.39 & 399 \\
\hline \multirow[t]{9}{*}{ No Photo } & \multirow[t]{3}{*}{ Male } & Male & 6.79 & 2.36 & 89 \\
\hline & & Female & 6.92 & 2.72 & 74 \\
\hline & & Total & 6.85 & 2.53 & 163 \\
\hline & \multirow[t]{3}{*}{ Female } & Male & 7.31 & 2.39 & 101 \\
\hline & & Female & 7.61 & 2.27 & 71 \\
\hline & & Total & 7.43 & 2.34 & 172 \\
\hline & \multirow[t]{3}{*}{ Total } & Male & 7.06 & 2.39 & 190 \\
\hline & & Female & 7.26 & 2.53 & 145 \\
\hline & & Total & 7.15 & 2.45 & 335 \\
\hline \multirow[t]{9}{*}{ Total } & \multirow[t]{3}{*}{ Male } & Male & 7.01 & 2.39 & 281 \\
\hline & & Female & 6.88 & 2.46 & 301 \\
\hline & & Total & $6.95 *$ & $2.42 *$ & 582 \\
\hline & \multirow[t]{3}{*}{ Female } & Male & 7.23 & 2.30 & 277 \\
\hline & & Female & 7.31 & 2.34 & 245 \\
\hline & & Total & $7.27 *$ & $2.32 *$ & 522 \\
\hline & \multirow[t]{3}{*}{ Total } & Male & 7.12 & 2.35 & 558 \\
\hline & & Female & 7.08 & 2.41 & 546 \\
\hline & & Total & 7.10 & 2.38 & 1104 \\
\hline
\end{tabular}

Note: One asterisk indicates the means and standard deviations involved in the significant main effect for Teacher Gender. 
Table 6

Sex Offense was Committed Ratings as a Function of Attractiveness Level, Teacher Gender, and Student Gender.

\begin{tabular}{|c|c|c|c|c|c|}
\hline Attractiveness Level & Teacher Gender & Student Gender & Mean & $S D$ & $N$ \\
\hline \multirow[t]{9}{*}{ Attractive } & \multirow[t]{3}{*}{ Male } & Male & 4.08 & 2.79 & 90 \\
\hline & & Female & 4.51 & 2.75 & 107 \\
\hline & & Total & 4.31 & 2.77 & 197 \\
\hline & \multirow{3}{*}{ Female } & Male & 4.16 & 2.69 & 85 \\
\hline & & Female & 4.02 & 2.69 & 88 \\
\hline & & Total & 4.09 & 2.68 & 173 \\
\hline & \multirow[t]{3}{*}{ Total } & Male & 4.12 & 2.73 & 175 \\
\hline & & Female & 4.29 & 2.72 & 195 \\
\hline & & Total & 4.21 & 2.73 & 370 \\
\hline \multirow[t]{9}{*}{ Unattractive } & \multirow[t]{3}{*}{ Male } & Male & 4.46 & 2.77 & 102 \\
\hline & & Female & 4.43 & 2.70 & 120 \\
\hline & & Total & 4.44 & 2.73 & 222 \\
\hline & \multirow[t]{3}{*}{ Female } & Male & 3.97 & 2.75 & 91 \\
\hline & & Female & 4.08 & 2.78 & 86 \\
\hline & & Total & 4.02 & 2.76 & 177 \\
\hline & \multirow[t]{3}{*}{ Total } & Male & 4.23 & 2.77 & 193 \\
\hline & & Female & 4.28 & 2.73 & 206 \\
\hline & & Total & 4.26 & 2.75 & 399 \\
\hline \multirow[t]{9}{*}{ No Photo } & \multirow[t]{3}{*}{ Male } & Male & 4.71 & 2.77 & 89 \\
\hline & & Female & 5.08 & 3.01 & 74 \\
\hline & & Total & 4.88 & 2.88 & 163 \\
\hline & \multirow[t]{3}{*}{ Female } & Male & 4.34 & 2.80 & 101 \\
\hline & & Female & 3.28 & 2.52 & 71 \\
\hline & & Total & 3.90 & 2.73 & 172 \\
\hline & \multirow[t]{3}{*}{ Total } & Male & 4.51 & 2.78 & 190 \\
\hline & & Female & 4.20 & 2.92 & 145 \\
\hline & & Total & 4.38 & 2.84 & 335 \\
\hline \multirow[t]{9}{*}{ Total } & \multirow[t]{3}{*}{ Male } & Male & 4.42 & 2.78 & 281 \\
\hline & & Female & 4.62 & 2.80 & 301 \\
\hline & & Total & $4.52 *$ & $2.79 *$ & 582 \\
\hline & \multirow[t]{3}{*}{ Female } & Male & 4.16 & 2.74 & 277 \\
\hline & & Female & 3.83 & 2.69 & 245 \\
\hline & & Total & $4.01 *$ & $2.72 *$ & 522 \\
\hline & \multirow[t]{3}{*}{ Total } & Male & 4.29 & 2.76 & 558 \\
\hline & & Female & 4.26 & 2.78 & 546 \\
\hline & & Total & 4.28 & 2.77 & 1104 \\
\hline
\end{tabular}

Note: One asterisk indicates the means and standard deviations involved in the significant main effect for Teacher Gender. 
Table 7

Likelihood of Reoffending Ratings as a Function of Attractiveness Level, Teacher Gender, and Student Gender.

\begin{tabular}{|c|c|c|c|c|c|}
\hline Attractiveness Level & Teacher Gender & Student Gender & Mean & $S D$ & $N$ \\
\hline \multirow[t]{9}{*}{ Attractive } & \multirow[t]{3}{*}{ Male } & Male & 7.25 & 2.71 & 20 \\
\hline & & Female & 7.28 & 2.60 & 29 \\
\hline & & Total & 7.27 & 2.62 & 49 \\
\hline & \multirow{3}{*}{ Female } & Male & 6.38 & 2.16 & 21 \\
\hline & & Female & 6.33 & 2.65 & 24 \\
\hline & & Total & 6.36 & 2.40 & 45 \\
\hline & \multirow[t]{3}{*}{ Total } & Male & 6.80 & 2.45 & 41 \\
\hline & & Female & 6.85 & 2.64 & 53 \\
\hline & & Total & 6.83 & 2.55 & 94 \\
\hline \multirow[t]{9}{*}{ Unattractive } & \multirow[t]{3}{*}{ Male } & Male & 7.79 & 1.93 & 29 \\
\hline & & Female & 6.40 & 2.43 & 30 \\
\hline & & Total & 7.08 & 2.29 & 59 \\
\hline & \multirow[t]{3}{*}{ Female } & Male & 6.04 & 2.46 & 26 \\
\hline & & Female & 7.06 & 2.75 & 18 \\
\hline & & Total & 6.45 & 2.60 & 44 \\
\hline & \multirow[t]{3}{*}{ Total } & Male & 6.96 & 2.35 & 55 \\
\hline & & Female & 6.65 & 2.55 & 48 \\
\hline & & Total & 6.82 & 2.44 & 103 \\
\hline \multirow[t]{9}{*}{ No Photo } & \multirow[t]{3}{*}{ Male } & Male & 7.22 & 2.28 & 27 \\
\hline & & Female & 6.75 & 2.75 & 24 \\
\hline & & Total & 7.00 & 2.50 & 51 \\
\hline & \multirow[t]{3}{*}{ Female } & Male & 6.60 & 2.90 & 25 \\
\hline & & Female & 7.10 & 2.42 & 10 \\
\hline & & Total & 6.74 & 2.75 & 35 \\
\hline & \multirow[t]{3}{*}{ Total } & Male & 6.92 & 2.59 & 52 \\
\hline & & Female & 6.85 & 2.63 & 34 \\
\hline & & Total & 6.90 & 2.59 & 86 \\
\hline \multirow[t]{9}{*}{ Total } & \multirow[t]{3}{*}{ Male } & Male & 7.45 & 2.27 & 76 \\
\hline & & Female & 6.81 & 2.58 & 83 \\
\hline & & Total & 7.11 & 2.45 & 159 \\
\hline & \multirow[t]{3}{*}{ Female } & Male & 6.33 & 2.52 & 72 \\
\hline & & Female & 6.73 & 2.62 & 52 \\
\hline & & Total & 6.50 & 2.56 & 124 \\
\hline & \multirow[t]{3}{*}{ Total } & Male & 6.91 & 2.45 & 148 \\
\hline & & Female & 6.78 & 2.59 & 135 \\
\hline & & Total & 6.84 & 2.51 & 283 \\
\hline
\end{tabular}


Table 8

Sex Offender Registration Ratings as a Function of Attractiveness Level, Teacher Gender, and Student Gender.

\begin{tabular}{|c|c|c|c|c|c|}
\hline Attractiveness Level & Teacher Gender & Student Gender & Mean & $S D$ & $N$ \\
\hline \multirow[t]{9}{*}{ Attractive } & \multirow[t]{3}{*}{ Male } & Male & 7.75 & 2.84 & 20 \\
\hline & & Female & 8.00 & 2.84 & 29 \\
\hline & & Total & 7.90 & 2.82 & 49 \\
\hline & \multirow{3}{*}{ Female } & Male & 7.29 & 3.24 & 21 \\
\hline & & Female & 8.08 & 2.55 & 24 \\
\hline & & Total & 7.71 & 2.89 & 45 \\
\hline & \multirow[t]{3}{*}{ Total } & Male & 7.51 & 3.03 & 41 \\
\hline & & Female & 8.04 & 2.69 & 53 \\
\hline & & Total & 7.81 & 2.84 & 94 \\
\hline \multirow[t]{9}{*}{ Unattractive } & \multirow[t]{3}{*}{ Male } & Male & 8.38 & 1.90 & 29 \\
\hline & & Female & 8.03 & 2.43 & 30 \\
\hline & & Total & 8.20 & 2.17 & 59 \\
\hline & \multirow[t]{3}{*}{ Female } & Male & 8.12 & 1.82 & 26 \\
\hline & & Female & 8.50 & 2.26 & 18 \\
\hline & & Total & 8.27 & 1.99 & 44 \\
\hline & \multirow[t]{3}{*}{ Total } & Male & 8.25 & 1.85 & 55 \\
\hline & & Female & 8.21 & 2.35 & 48 \\
\hline & & Total & 8.23 & 2.09 & 103 \\
\hline \multirow[t]{9}{*}{ No Photo } & \multirow[t]{3}{*}{ Male } & Male & 8.59 & 1.74 & 27 \\
\hline & & Female & 8.00 & 2.52 & 24 \\
\hline & & Total & 8.31 & 2.14 & 51 \\
\hline & \multirow[t]{3}{*}{ Female } & Male & 8.24 & 2.11 & 25 \\
\hline & & Female & 7.80 & 3.01 & 10 \\
\hline & & Total & 8.11 & 2.36 & 35 \\
\hline & \multirow[t]{3}{*}{ Total } & Male & 8.42 & 1.91 & 52 \\
\hline & & Female & 7.94 & 2.63 & 34 \\
\hline & & Total & 8.23 & 2.22 & 86 \\
\hline \multirow[t]{9}{*}{ Total } & \multirow[t]{3}{*}{ Male } & Male & 8.29 & 2.13 & 76 \\
\hline & & Female & 8.01 & 2.57 & 83 \\
\hline & & Total & 8.14 & 2.37 & 159 \\
\hline & \multirow[t]{3}{*}{ Female } & Male & 7.92 & 2.41 & 72 \\
\hline & & Female & 8.17 & 2.51 & 52 \\
\hline & & Total & 8.02 & 2.44 & 124 \\
\hline & \multirow[t]{3}{*}{ Total } & Male & 8.11 & 2.27 & 148 \\
\hline & & Female & 8.07 & 2.54 & 135 \\
\hline & & Total & 8.09 & 2.40 & 283 \\
\hline
\end{tabular}


Table 9

Sex Offender Treatment Ratings as a Function of Attractiveness Level, Teacher Gender, and Student Gender.

\begin{tabular}{|c|c|c|c|c|c|}
\hline Attractiveness Level & Teacher Gender & Student Gender & Mean & $S D$ & $N$ \\
\hline \multirow[t]{9}{*}{ Attractive } & \multirow[t]{3}{*}{ Male } & Male & 7.85 & 2.58 & 20 \\
\hline & & Female & 7.90 & 2.68 & 29 \\
\hline & & Total & 7.88 & 2.61 & 49 \\
\hline & \multirow[t]{3}{*}{ Female } & Male & 7.29 & 2.74 & 21 \\
\hline & & Female & 7.79 & 2.06 & 24 \\
\hline & & Total & 7.56 & 2.39 & 45 \\
\hline & \multirow[t]{3}{*}{ Total } & Male & 7.56 & 2.65 & 41 \\
\hline & & Female & 7.85 & 2.40 & 53 \\
\hline & & Total & $7.72 *$ & $2.50 *$ & 94 \\
\hline \multirow[t]{9}{*}{ Unattractive } & \multirow[t]{3}{*}{ Male } & Male & 7.24 & 2.29 & 29 \\
\hline & & Female & 8.17 & 1.78 & 30 \\
\hline & & Total & 7.71 & 2.08 & 59 \\
\hline & \multirow[t]{3}{*}{ Female } & Male & 7.35 & 2.04 & 26 \\
\hline & & Female & 7.78 & 2.18 & 18 \\
\hline & & Total & 7.52 & 2.09 & 44 \\
\hline & \multirow{3}{*}{ Total } & Male & 7.29 & 2.16 & 55 \\
\hline & & Female & 8.02 & 1.93 & 48 \\
\hline & & Total & $7.63 *$ & $2.08 *$ & 103 \\
\hline \multirow[t]{9}{*}{ No Photo } & \multirow[t]{3}{*}{ Male } & Male & 8.22 & 1.95 & 27 \\
\hline & & Female & 8.54 & 1.82 & 24 \\
\hline & & Total & 8.37 & 1.88 & 51 \\
\hline & \multirow[t]{3}{*}{ Female } & Male & 8.16 & 1.70 & 25 \\
\hline & & Female & 8.70 & 1.42 & 10 \\
\hline & & Total & 8.31 & 1.62 & 35 \\
\hline & \multirow[t]{3}{*}{ Total } & Male & 8.19 & 1.82 & 52 \\
\hline & & Female & 8.59 & 1.69 & 34 \\
\hline & & Total & $8.35^{*}$ & $1.77 *$ & 86 \\
\hline \multirow[t]{9}{*}{ Total } & \multirow[t]{3}{*}{ Male } & Male & 7.75 & 2.27 & 76 \\
\hline & & Female & 8.18 & 2.14 & 83 \\
\hline & & Total & 7.97 & 2.20 & 159 \\
\hline & \multirow[t]{3}{*}{ Female } & Male & 7.61 & 2.17 & 72 \\
\hline & & Female & 7.96 & 2.00 & 52 \\
\hline & & Total & 7.76 & 2.10 & 124 \\
\hline & \multirow[t]{3}{*}{ Total } & Male & 7.68 & 2.22 & 148 \\
\hline & & Female & 8.10 & 2.08 & 135 \\
\hline & & Total & 7.88 & 2.16 & 283 \\
\hline
\end{tabular}

Note: One asterisk indicates the means and standard deviations involved in the significant main effect for Attractiveness Level. 
Table 10

Community Notification Ratings as a Function of Attractiveness Level, Teacher Gender, and Student Gender.

\begin{tabular}{|c|c|c|c|c|c|}
\hline Attractiveness Level & Teacher Gender & Student Gender & Mean & $S D$ & $N$ \\
\hline \multirow[t]{9}{*}{ Attractive } & \multirow[t]{3}{*}{ Male } & Male & 7.30 & 2.96 & 20 \\
\hline & & Female & 7.52 & 2.91 & 29 \\
\hline & & Total & 7.43 & 2.90 & 49 \\
\hline & \multirow{3}{*}{ Female } & Male & 6.86 & 2.83 & 21 \\
\hline & & Female & 7.67 & 2.30 & 24 \\
\hline & & Total & 7.29 & 2.56 & 45 \\
\hline & \multirow[t]{3}{*}{ Total } & Male & 7.07 & 2.87 & 41 \\
\hline & & Female & 7.58 & 2.63 & 53 \\
\hline & & Total & 7.36 & 2.73 & 94 \\
\hline \multirow[t]{9}{*}{ Unattractive } & \multirow[t]{3}{*}{ Male } & Male & 7.79 & 2.11 & 29 \\
\hline & & Female & 8.00 & 2.10 & 30 \\
\hline & & Total & 7.90 & 2.09 & 59 \\
\hline & \multirow[t]{3}{*}{ Female } & Male & 7.69 & 2.09 & 26 \\
\hline & & Female & 8.17 & 2.09 & 18 \\
\hline & & Total & 7.89 & 2.08 & 44 \\
\hline & \multirow[t]{3}{*}{ Total } & Male & 7.75 & 2.08 & 55 \\
\hline & & Female & 8.06 & 2.08 & 48 \\
\hline & & Total & 7.89 & 2.08 & 103 \\
\hline \multirow[t]{9}{*}{ No Photo } & \multirow[t]{3}{*}{ Male } & Male & 7.81 & 2.54 & 27 \\
\hline & & Female & 7.67 & 2.78 & 24 \\
\hline & & Total & 7.75 & 2.63 & 51 \\
\hline & \multirow[t]{3}{*}{ Female } & Male & 8.20 & 1.71 & 25 \\
\hline & & Female & 8.30 & 2.83 & 10 \\
\hline & & Total & 8.23 & 2.04 & 35 \\
\hline & \multirow[t]{3}{*}{ Total } & Male & 8.00 & 2.17 & 52 \\
\hline & & Female & 7.85 & 2.76 & 34 \\
\hline & & Total & 7.94 & 2.41 & 86 \\
\hline \multirow[t]{9}{*}{ Total } & \multirow[t]{3}{*}{ Male } & Male & 7.67 & 2.48 & 76 \\
\hline & & Female & 7.73 & 2.58 & 83 \\
\hline & & Total & 7.70 & 2.53 & 159 \\
\hline & \multirow[t]{3}{*}{ Female } & Male & 7.63 & 2.25 & 72 \\
\hline & & Female & 7.96 & 2.31 & 52 \\
\hline & & Total & 7.77 & 2.27 & 124 \\
\hline & \multirow[t]{3}{*}{ Total } & Male & 7.65 & 2.37 & 148 \\
\hline & & Female & 7.82 & 2.47 & 135 \\
\hline & & Total & 7.73 & 2.42 & 283 \\
\hline
\end{tabular}


Table 11

Teacher Responsibility Ratings as a Function of Attractiveness Level, Teacher Gender, and Student Gender.

\begin{tabular}{|c|c|c|c|c|c|}
\hline Attractiveness Level & Teacher Gender & Student Gender & Mean & $S D$ & $N$ \\
\hline \multirow[t]{9}{*}{ Attractive } & \multirow[t]{3}{*}{ Male } & Male & 17.11 & 8.71 & 90 \\
\hline & & Female & 19.21 & 8.29 & 107 \\
\hline & & Total & 18.25 & 8.52 & 197 \\
\hline & \multirow{3}{*}{ Female } & Male & 16.68 & 8.60 & 85 \\
\hline & & Female & 16.36 & 9.05 & 88 \\
\hline & & Total & 16.52 & 8.81 & 173 \\
\hline & \multirow[t]{3}{*}{ Total } & Male & 16.90 & 8.63 & 175 \\
\hline & & Female & 17.93 & 8.73 & 195 \\
\hline & & Total & 17.44 & 8.69 & 370 \\
\hline \multirow[t]{9}{*}{ Unattractive } & \multirow[t]{3}{*}{ Male } & Male & 17.67 & 8.35 & 102 \\
\hline & & Female & 18.40 & 8.86 & 120 \\
\hline & & Total & 18.06 & 8.62 & 222 \\
\hline & \multirow[t]{3}{*}{ Female } & Male & 16.85 & 9.27 & 91 \\
\hline & & Female & 15.12 & 9.43 & 86 \\
\hline & & Total & 16.01 & 9.36 & 177 \\
\hline & \multirow[t]{3}{*}{ Total } & Male & 17.28 & 8.78 & 193 \\
\hline & & Female & 17.03 & 9.22 & 206 \\
\hline & & Total & 17.15 & 9.00 & 399 \\
\hline \multirow[t]{9}{*}{ No Photo } & \multirow[t]{3}{*}{ Male } & Male & 18.38 & 8.22 & 89 \\
\hline & & Female & 18.18 & 9.10 & 74 \\
\hline & & Total & 18.29 & 8.60 & 163 \\
\hline & \multirow[t]{3}{*}{ Female } & Male & 18.04 & 8.64 & 101 \\
\hline & & Female & 14.79 & 9.27 & 71 \\
\hline & & Total & 16.70 & 9.02 & 172 \\
\hline & \multirow[t]{3}{*}{ Total } & Male & 18.20 & 8.42 & 190 \\
\hline & & Female & 16.52 & 9.31 & 145 \\
\hline & & Total & 17.47 & 8.84 & 335 \\
\hline \multirow[t]{9}{*}{ Total } & \multirow[t]{3}{*}{ Male } & Male & 17.72 & 8.41 & 281 \\
\hline & & Female & 18.63 & 8.71 & 301 \\
\hline & & Total & 18.19 & 8.57 & 582 \\
\hline & \multirow[t]{3}{*}{ Female } & Male & 17.23 & 8.83 & 277 \\
\hline & & Female & 15.47 & 9.24 & 245 \\
\hline & & Total & 16.40 & 9.06 & 522 \\
\hline & \multirow[t]{3}{*}{ Total } & Male & 17.47 & 8.62 & 558 \\
\hline & & Female & 17.21 & 9.08 & 546 \\
\hline & & Total & 17.35 & 8.84 & 1104 \\
\hline
\end{tabular}


Table 12

Teacher Credibility Ratings as a Function of Attractiveness Level, Teacher Gender, and Student Gender.

\begin{tabular}{|c|c|c|c|c|c|}
\hline Attractiveness Level & Teacher Gender & Student Gender & Mean & $S D$ & $N$ \\
\hline \multirow[t]{9}{*}{ Attractive } & \multirow[t]{3}{*}{ Male } & Male & 23.92 & 10.02 & 90 \\
\hline & & Female & 21.74 & 9.09 & 107 \\
\hline & & Total & 22.74 & 9.57 & 197 \\
\hline & \multirow[t]{3}{*}{ Female } & Male & 24.18 & 8.44 & 85 \\
\hline & & Female & 23.70 & 10.23 & 88 \\
\hline & & Total & 23.94 & 9.37 & 173 \\
\hline & \multirow[t]{3}{*}{ Total } & Male & 24.05 & 9.26 & 175 \\
\hline & & Female & 22.63 & 9.65 & 195 \\
\hline & & Total & 23.30 & 9.48 & 370 \\
\hline \multirow[t]{9}{*}{ Unattractive } & \multirow[t]{3}{*}{ Male } & Male & 21.83 & 9.39 & 102 \\
\hline & & Female & 23.25 & 9.68 & 120 \\
\hline & & Total & 22.60 & 9.56 & 222 \\
\hline & \multirow[t]{3}{*}{ Female } & Male & 23.77 & 9.03 & 91 \\
\hline & & Female & 23.22 & 9.89 & 86 \\
\hline & & Total & 23.50 & 9.43 & 177 \\
\hline & \multirow[t]{3}{*}{ Total } & Male & 22.75 & 9.25 & 193 \\
\hline & & Female & 23.24 & 9.75 & 206 \\
\hline & & Total & 23.00 & 9.50 & 399 \\
\hline \multirow[t]{9}{*}{ No Photo } & \multirow[t]{3}{*}{ Male } & Male & 21.60 & 9.60 & 89 \\
\hline & & Female & 21.26 & 9.61 & 74 \\
\hline & & Total & 21.44 & 9.57 & 163 \\
\hline & \multirow[t]{3}{*}{ Female } & Male & 24.04 & 9.25 & 101 \\
\hline & & Female & 28.20 & 8.54 & 71 \\
\hline & & Total & 25.76 & 9.17 & 172 \\
\hline & \multirow[t]{3}{*}{ Total } & Male & 22.89 & 9.47 & 190 \\
\hline & & Female & 24.66 & 9.71 & 145 \\
\hline & & Total & 23.66 & 9.60 & 335 \\
\hline \multirow[t]{9}{*}{ Total } & \multirow[t]{3}{*}{ Male } & Male & 22.43 & 9.68 & 281 \\
\hline & & Female & 22.22 & 9.47 & 301 \\
\hline & & Total & $22.32 *$ & $9.56^{*}$ & 582 \\
\hline & \multirow[t]{3}{*}{ Female } & Male & 23.99 & 8.90 & 277 \\
\hline & & Female & 24.84 & 9.85 & 245 \\
\hline & & Total & $24.39 *$ & $9.36^{*}$ & 522 \\
\hline & \multirow[t]{3}{*}{ Total } & Male & 23.20 & 9.33 & 558 \\
\hline & & Female & 23.40 & 9.72 & 546 \\
\hline & & Total & 23.30 & 9.52 & 1104 \\
\hline
\end{tabular}

Note: One asterisk indicates the means and standard deviations involved in the significant main effect for Teacher Gender. 
Table 13

Teacher Empathy Ratings as a Function of Attractiveness Level, Teacher Gender, and Student Gender.

\begin{tabular}{|c|c|c|c|c|c|}
\hline Attractiveness Level & Teacher Gender & Student Gender & Mean & $S D$ & $N$ \\
\hline \multirow[t]{9}{*}{ Attractive } & \multirow[t]{3}{*}{ Male } & Male & 14.68 & 8.39 & 90 \\
\hline & & Female & 14.33 & 8.20 & 107 \\
\hline & & Total & 14.49 & 8.27 & 197 \\
\hline & \multirow[t]{3}{*}{ Female } & Male & 13.95 & 7.94 & 85 \\
\hline & & Female & 14.81 & 9.65 & 88 \\
\hline & & Total & 14.39 & 8.83 & 173 \\
\hline & \multirow[t]{3}{*}{ Total } & Male & 14.33 & 8.16 & 175 \\
\hline & & Female & 14.54 & 8.86 & 195 \\
\hline & & Total & 14.44 & 8.53 & 370 \\
\hline \multirow[t]{9}{*}{ Unattractive } & \multirow[t]{3}{*}{ Male } & Male & 13.37 & 8.78 & 102 \\
\hline & & Female & 13.71 & 8.62 & 120 \\
\hline & & Total & 13.55 & 8.68 & 222 \\
\hline & \multirow[t]{3}{*}{ Female } & Male & 15.10 & 8.59 & 91 \\
\hline & & Female & 14.59 & 8.97 & 86 \\
\hline & & Total & 14.85 & 8.76 & 177 \\
\hline & \multirow[t]{3}{*}{ Total } & Male & 14.19 & 8.71 & 193 \\
\hline & & Female & 14.08 & 8.76 & 206 \\
\hline & & Total & 14.13 & 8.73 & 399 \\
\hline \multirow[t]{9}{*}{ No Photo } & \multirow[t]{3}{*}{ Male } & Male & 15.56 & 7.61 & 89 \\
\hline & & Female & 13.78 & 8.37 & 74 \\
\hline & & Total & 14.75 & 7.99 & 163 \\
\hline & \multirow[t]{3}{*}{ Female } & Male & 14.13 & 8.94 & 101 \\
\hline & & Female & 17.23 & 8.69 & 71 \\
\hline & & Total & 15.41 & 8.94 & 172 \\
\hline & \multirow[t]{3}{*}{ Total } & Male & 14.80 & 8.35 & 190 \\
\hline & & Female & 15.47 & 8.67 & 145 \\
\hline & & Total & 15.09 & 8.49 & 335 \\
\hline \multirow[t]{9}{*}{ Total } & \multirow[t]{3}{*}{ Male } & Male & 14.48 & 8.32 & 281 \\
\hline & & Female & 13.95 & 8.39 & 301 \\
\hline & & Total & 14.21 & 8.35 & 582 \\
\hline & \multirow[t]{3}{*}{ Female } & Male & 14.39 & 8.51 & 277 \\
\hline & & Female & 15.43 & 9.18 & 245 \\
\hline & & Total & 14.88 & 8.84 & 522 \\
\hline & \multirow[t]{3}{*}{ Total } & Male & 14.44 & 8.41 & 558 \\
\hline & & Female & 14.61 & 8.78 & 546 \\
\hline & & Total & 14.53 & 8.59 & 1104 \\
\hline
\end{tabular}


Table 14

Student Blameworthiness Ratings as a Function of Attractiveness Level, Teacher Gender, and Student Gender.

\begin{tabular}{|c|c|c|c|c|c|}
\hline Attractiveness Level & Teacher Gender & Student Gender & Mean & $S D$ & $N$ \\
\hline \multirow[t]{9}{*}{ Attractive } & \multirow[t]{3}{*}{ Male } & Male & 17.54 & 10.70 & 90 \\
\hline & & Female & 17.41 & 10.97 & 107 \\
\hline & & Total & 17.47 & 10.82 & 197 \\
\hline & \multirow{3}{*}{ Female } & Male & 17.09 & 9.28 & 85 \\
\hline & & Female & 15.89 & 9.33 & 88 \\
\hline & & Total & 16.48 & 9.30 & 173 \\
\hline & \multirow[t]{3}{*}{ Total } & Male & 17.33 & 10.01 & 175 \\
\hline & & Female & 16.72 & 10.27 & 195 \\
\hline & & Total & 17.01 & 10.14 & 370 \\
\hline \multirow[t]{9}{*}{ Unattractive } & \multirow[t]{3}{*}{ Male } & Male & 16.67 & 10.95 & 102 \\
\hline & & Female & 17.45 & 10.52 & 120 \\
\hline & & Total & 17.09 & 10.71 & 222 \\
\hline & \multirow[t]{3}{*}{ Female } & Male & 17.00 & 10.54 & 91 \\
\hline & & Female & 15.43 & 10.19 & 86 \\
\hline & & Total & 16.24 & 10.37 & 177 \\
\hline & \multirow[t]{3}{*}{ Total } & Male & 16.82 & 10.73 & 193 \\
\hline & & Female & 16.61 & 10.41 & 206 \\
\hline & & Total & 16.71 & 10.55 & 399 \\
\hline \multirow[t]{9}{*}{ No Photo } & \multirow[t]{3}{*}{ Male } & Male & 16.40 & 10.64 & 89 \\
\hline & & Female & 17.81 & 11.09 & 74 \\
\hline & & Total & 17.04 & 10.83 & 163 \\
\hline & \multirow[t]{3}{*}{ Female } & Male & 16.80 & 10.28 & 101 \\
\hline & & Female & 15.92 & 10.61 & 71 \\
\hline & & Total & 16.44 & 10.39 & 172 \\
\hline & \multirow[t]{3}{*}{ Total } & Male & 16.62 & 10.42 & 190 \\
\hline & & Female & 16.88 & 10.86 & 145 \\
\hline & & Total & 16.73 & 10.60 & 335 \\
\hline \multirow[t]{9}{*}{ Total } & \multirow[t]{3}{*}{ Male } & Male & 16.86 & 10.74 & 281 \\
\hline & & Female & 17.52 & 10.79 & 301 \\
\hline & & Total & 17.21 & 10.76 & 582 \\
\hline & \multirow[t]{3}{*}{ Female } & Male & 16.96 & 10.03 & 277 \\
\hline & & Female & 15.73 & 9.98 & 245 \\
\hline & & Total & 16.38 & 10.02 & 522 \\
\hline & \multirow[t]{3}{*}{ Total } & Male & 16.91 & 10.39 & 558 \\
\hline & & Female & 16.72 & 10.46 & 546 \\
\hline & & Total & 16.82 & 10.42 & 1104 \\
\hline
\end{tabular}


Table 15

Student Responsibility Ratings as a Function of Attractiveness Level, Teacher Gender, and Student Gender.

\begin{tabular}{|c|c|c|c|c|c|}
\hline Attractiveness Level & Teacher Gender & Student Gender & Mean & $S D$ & $N$ \\
\hline \multirow[t]{9}{*}{ Attractive } & \multirow[t]{3}{*}{ Male } & Male & 13.37 & 8.93 & 90 \\
\hline & & Female & 13.47 & 8.15 & 107 \\
\hline & & Total & 13.42 & 8.49 & 197 \\
\hline & \multirow[t]{3}{*}{ Female } & Male & 14.02 & 8.43 & 85 \\
\hline & & Female & 13.77 & 9.40 & 88 \\
\hline & & Total & 13.90 & 8.91 & 173 \\
\hline & \multirow{3}{*}{ Total } & Male & 13.69 & 8.67 & 175 \\
\hline & & Female & 13.61 & 8.72 & 195 \\
\hline & & Total & 13.64 & 8.68 & 370 \\
\hline \multirow[t]{9}{*}{ Unattractive } & \multirow[t]{3}{*}{ Male } & Male & 12.53 & 7.78 & 102 \\
\hline & & Female & 14.12 & 8.67 & 120 \\
\hline & & Total & 13.39 & 8.29 & 222 \\
\hline & \multirow[t]{3}{*}{ Female } & Male & 12.78 & 7.93 & 91 \\
\hline & & Female & 14.90 & 9.40 & 86 \\
\hline & & Total & 13.81 & 8.72 & 177 \\
\hline & \multirow[t]{3}{*}{ Total } & Male & 12.65 & 7.83 & 193 \\
\hline & & Female & 14.44 & 8.97 & 206 \\
\hline & & Total & 13.57 & 8.48 & 399 \\
\hline \multirow[t]{9}{*}{ No Photo } & \multirow[t]{3}{*}{ Male } & Male & 12.99 & 8.27 & 89 \\
\hline & & Female & 13.04 & 9.18 & 74 \\
\hline & & Total & 13.01 & 8.67 & 163 \\
\hline & \multirow[t]{3}{*}{ Female } & Male & 12.86 & 8.20 & 101 \\
\hline & & Female & 13.90 & 8.78 & 71 \\
\hline & & Total & 13.29 & 8.43 & 172 \\
\hline & \multirow[t]{3}{*}{ Total } & Male & 12.92 & 8.21 & 190 \\
\hline & & Female & 13.46 & 8.96 & 145 \\
\hline & & Total & 13.16 & 8.54 & 335 \\
\hline \multirow[t]{9}{*}{ Total } & \multirow[t]{3}{*}{ Male } & Male & 12.94 & 8.30 & 281 \\
\hline & & Female & 13.62 & 8.60 & 301 \\
\hline & & Total & 13.29 & 8.45 & 582 \\
\hline & \multirow[t]{3}{*}{ Female } & Male & 13.19 & 8.18 & 277 \\
\hline & & Female & 14.20 & 9.20 & 245 \\
\hline & & Total & 13.67 & 8.68 & 522 \\
\hline & \multirow[t]{3}{*}{ Total } & Male & 13.07 & 8.23 & 558 \\
\hline & & Female & 13.88 & 8.87 & 546 \\
\hline & & Total & 13.47 & 8.56 & 1104 \\
\hline
\end{tabular}


Table 16

Student Credibility Ratings as a Function of Attractiveness Level, Teacher Gender, and Student Gender.

\begin{tabular}{|c|c|c|c|c|c|}
\hline Attractiveness Level & Teacher Gender & Student Gender & Mean & $S D$ & $N$ \\
\hline \multirow[t]{9}{*}{ Attractive } & \multirow[t]{3}{*}{ Male } & Male & 17.03 & 9.12 & 90 \\
\hline & & Female & 17.91 & 8.11 & 107 \\
\hline & & Total & 17.51 & 8.57 & 197 \\
\hline & \multirow{3}{*}{ Female } & Male & 17.06 & 8.34 & 85 \\
\hline & & Female & 17.02 & 9.66 & 88 \\
\hline & & Total & 17.04 & 9.01 & 173 \\
\hline & \multirow[t]{3}{*}{ Total } & Male & 17.05 & 8.73 & 175 \\
\hline & & Female & 17.51 & 8.83 & 195 \\
\hline & & Total & 17.29 & 8.77 & 370 \\
\hline \multirow[t]{9}{*}{ Unattractive } & \multirow[t]{3}{*}{ Male } & Male & 16.55 & 8.54 & 102 \\
\hline & & Female & 17.47 & 7.39 & 120 \\
\hline & & Total & 17.05 & 7.93 & 222 \\
\hline & \multirow[t]{3}{*}{ Female } & Male & 16.18 & 8.45 & 91 \\
\hline & & Female & 15.95 & 9.81 & 86 \\
\hline & & Total & 16.07 & 9.11 & 177 \\
\hline & \multirow[t]{3}{*}{ Total } & Male & 16.37 & 8.48 & 193 \\
\hline & & Female & 16.83 & 8.49 & 206 \\
\hline & & Total & 16.61 & 8.48 & 399 \\
\hline \multirow[t]{9}{*}{ No Photo } & \multirow[t]{3}{*}{ Male } & Male & 18.84 & 8.76 & 89 \\
\hline & & Female & 18.66 & 8.69 & 74 \\
\hline & & Total & 18.76 & 8.70 & 163 \\
\hline & \multirow[t]{3}{*}{ Female } & Male & 17.33 & 8.92 & 101 \\
\hline & & Female & 14.96 & 9.03 & 71 \\
\hline & & Total & 16.35 & 9.01 & 172 \\
\hline & \multirow[t]{3}{*}{ Total } & Male & 18.04 & 8.85 & 190 \\
\hline & & Female & 16.85 & 9.02 & 145 \\
\hline & & Total & 17.52 & 8.93 & 335 \\
\hline \multirow[t]{9}{*}{ Total } & \multirow[t]{3}{*}{ Male } & Male & 17.43 & 8.82 & 281 \\
\hline & & Female & 17.92 & 7.97 & 301 \\
\hline & & Total & $17.68 *$ & $8.39 *$ & 582 \\
\hline & \multirow[t]{3}{*}{ Female } & Male & 16.87 & 8.58 & 277 \\
\hline & & Female & 16.05 & 9.53 & 245 \\
\hline & & Total & $16.48 *$ & $9.04 *$ & 522 \\
\hline & \multirow[t]{3}{*}{ Total } & Male & 17.15 & 8.70 & 558 \\
\hline & & Female & 17.08 & 8.75 & 546 \\
\hline & & Total & 17.12 & 8.72 & 1104 \\
\hline
\end{tabular}

Note: One asterisk indicates the means and standard deviations involved in the significant main effect for Teacher Gender. 
Table 17

Student Empathy Ratings as a Function of Attractiveness Level, Teacher Gender, and Student Gender.

\begin{tabular}{|c|c|c|c|c|c|}
\hline Attractiveness Level & Teacher Gender & Student Gender & Mean & $S D$ & $N$ \\
\hline \multirow[t]{9}{*}{ Attractive } & \multirow[t]{3}{*}{ Male } & Male & 13.26 & 7.90 & 90 \\
\hline & & Female & 15.26 & 7.77 & 107 \\
\hline & & Total & 14.35 & 7.87 & 197 \\
\hline & \multirow[t]{3}{*}{ Female } & Male & 14.59 & 7.84 & 85 \\
\hline & & Female & 14.18 & 8.99 & 88 \\
\hline & & Total & 14.38 & 8.42 & 173 \\
\hline & \multirow[t]{3}{*}{ Total } & Male & 13.90 & 7.87 & 175 \\
\hline & & Female & 14.77 & 8.34 & 195 \\
\hline & & Total & 14.36 & 8.12 & 370 \\
\hline \multirow[t]{9}{*}{ Unattractive } & \multirow[t]{3}{*}{ Male } & Male & 13.13 & 8.17 & 102 \\
\hline & & Female & 15.01 & 8.73 & 120 \\
\hline & & Total & 14.14 & 8.51 & 222 \\
\hline & \multirow[t]{3}{*}{ Female } & Male & 16.31 & 8.40 & 91 \\
\hline & & Female & 14.17 & 8.68 & 86 \\
\hline & & Total & 15.27 & 8.58 & 177 \\
\hline & \multirow[t]{3}{*}{ Total } & Male & 14.63 & 8.41 & 193 \\
\hline & & Female & 14.66 & 8.70 & 206 \\
\hline & & Total & 14.64 & 8.55 & 399 \\
\hline \multirow[t]{9}{*}{ No Photo } & \multirow[t]{3}{*}{ Male } & Male & 15.24 & 7.97 & 89 \\
\hline & & Female & 14.22 & 8.13 & 74 \\
\hline & & Total & 14.77 & 8.03 & 163 \\
\hline & \multirow[t]{3}{*}{ Female } & Male & 14.96 & 7.62 & 101 \\
\hline & & Female & 14.30 & 8.19 & 71 \\
\hline & & Total & 14.69 & 7.84 & 172 \\
\hline & \multirow[t]{3}{*}{ Total } & Male & 15.09 & 7.77 & 190 \\
\hline & & Female & 14.26 & 8.13 & 145 \\
\hline & & Total & 14.73 & 7.92 & 335 \\
\hline \multirow[t]{9}{*}{ Total } & \multirow[t]{3}{*}{ Male } & Male & 13.84 & 8.05 & 281 \\
\hline & & Female & 14.90 & 8.24 & 301 \\
\hline & & Total & 14.39 & 8.16 & 582 \\
\hline & \multirow[t]{3}{*}{ Female } & Male & 15.29 & 7.96 & 277 \\
\hline & & Female & 14.21 & 8.62 & 245 \\
\hline & & Total & 14.78 & 8.28 & 522 \\
\hline & \multirow[t]{3}{*}{ Total } & Male & 14.56 & 8.03 & 558 \\
\hline & & Female & 14.59 & 8.41 & 546 \\
\hline & & Total & 14.58 & 8.22 & 1104 \\
\hline
\end{tabular}




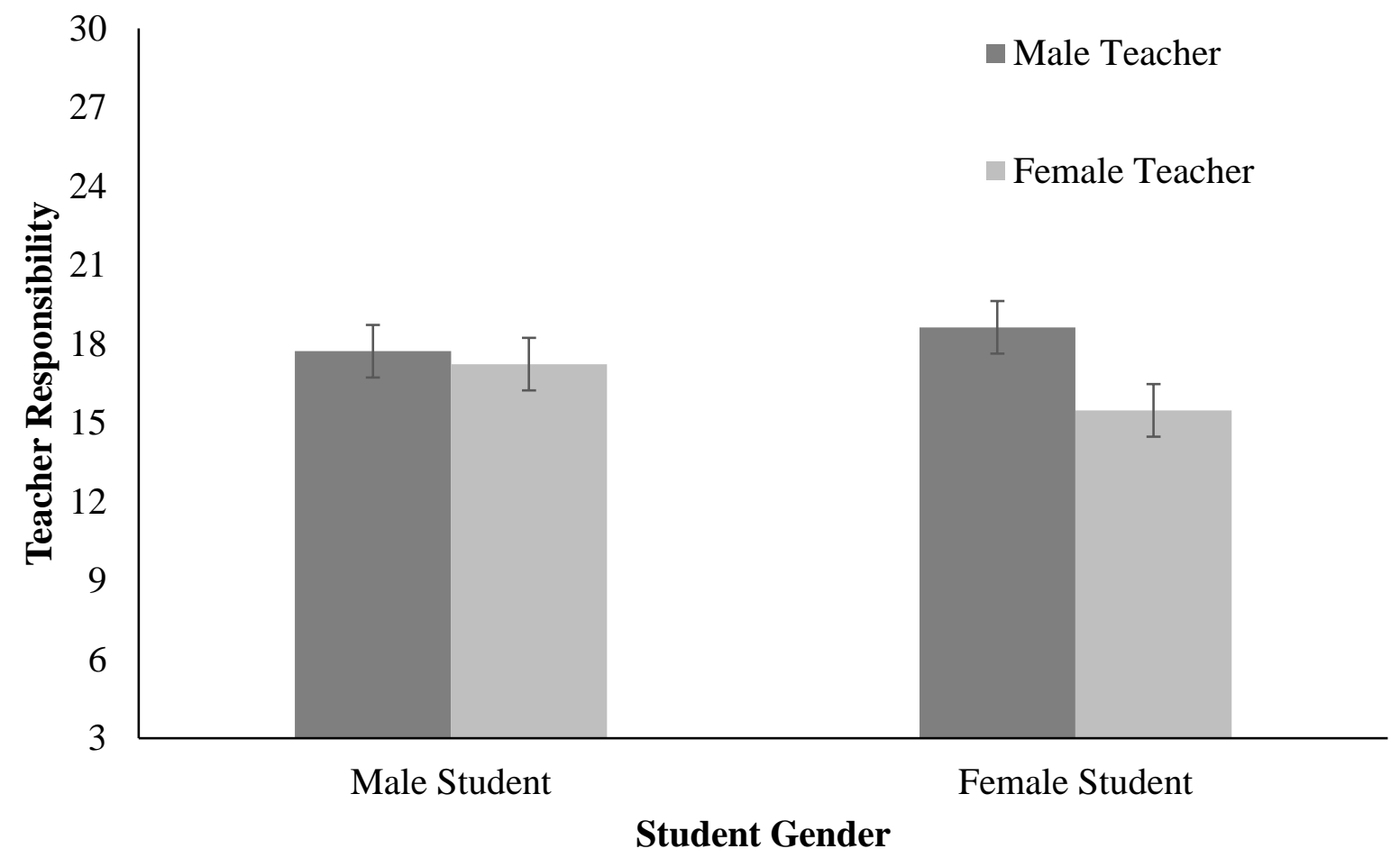

Figure 1.

Mean teacher responsibility ratings as a function of teacher gender and student gender. 


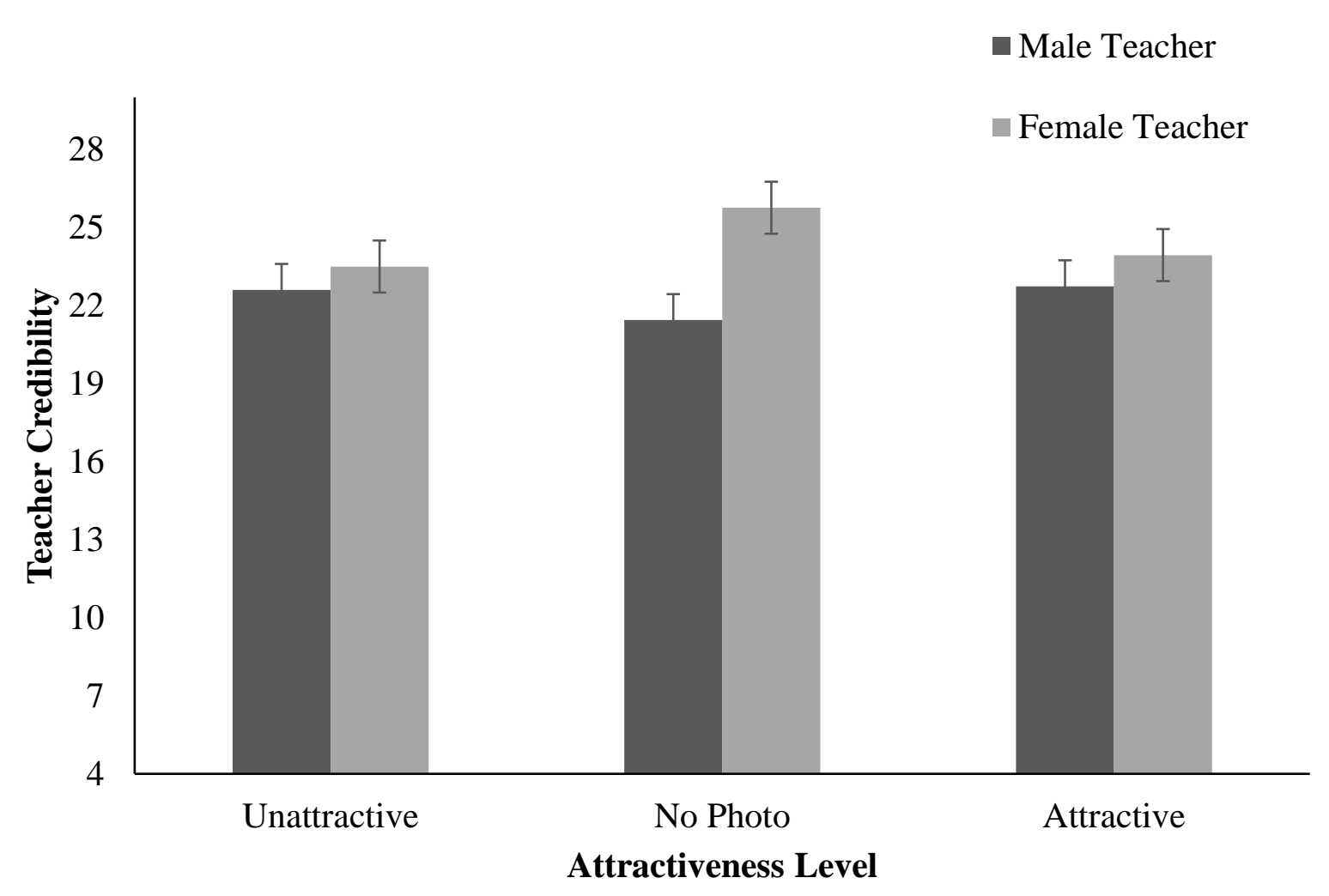

Figure 2.

Mean teacher credibility ratings as function of teacher gender and attractiveness level. 


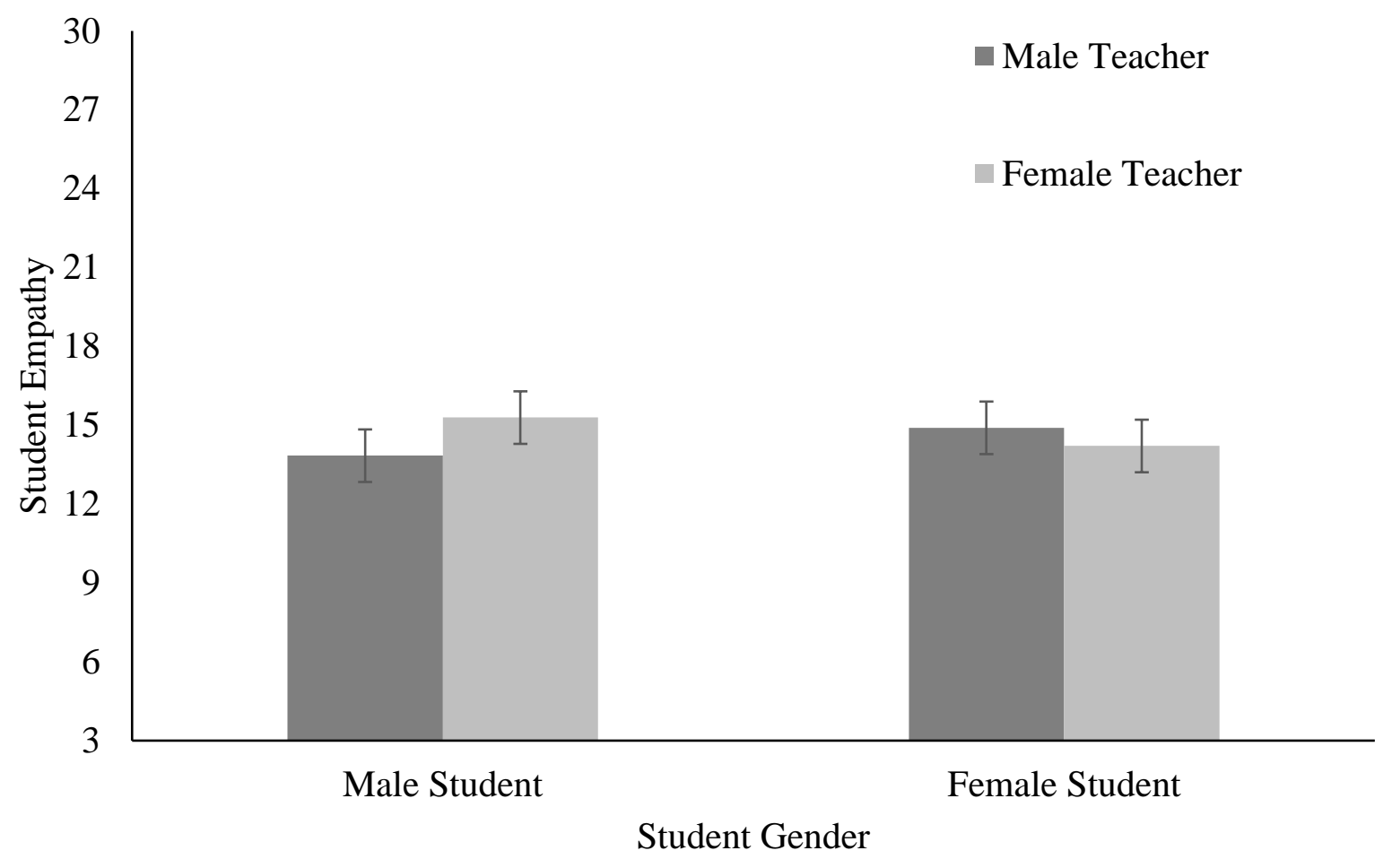

Figure 3.

Mean student empathy ratings as a function of teacher gender and student gender. 


\section{REFERENCES}

50 Hot Teachers That Slept With Their Students. (2016). Retrieved from

http://www.thebrofessional.net/bad-teachers/

Abbott, T. (2015). More teachers are having sex with their students. Here's how schools can stop them. Retrieved from

https://www.washingtonpost.com/posteverything/wp/2015/01/20/more-teachers-arehaving-sex-with-their-students-heres-how-schools-can-stop-

them/?utm_term=.b7e443f0e342

Abel, M. H., \& Watters, H. (2005). Attributions of guilt and punishment as functions of physical attractiveness and smiling. The Journal of Social Psychology, 145(6), 687-702. http://doi.org/10.3200/SOCP.145.6.687-703

Abwender, D. A., \& Hough, K. (2001). Interactive effects of characteristics of defendant and mock juror on U. S. participants' judgment and sentencing recommendations. The Journal of Social Psychology, 141(5), 603-615. http://doi.org/10.1080/00224540109600574

Ahola, A. S., Christianson, S. A., \& Hellstrom, A. (2009). Justice needs a blindfold: Effects of gender and attractiveness on prison sentences and attributions of personal characteristics in a judicial process. Psychiatry, Psychology and Law, 16, 90-100

American Association of University Women. (1993, 2001). Hostile hallways: The AAUW survey on sexual harassment in America's schools. Washington, D.C.: American Association of University Women. 
Anderson, I., \& Lyons, A. (2005). The effect of victims' social support on attributions of blame in female and male rape. Journal Of Applied Social Psychology, 35(7), 1400-1417. doi:10.1111/j.1559-1816.2005.tb02176.x

Austin, A. C., Plumm, K. M., Terrance, C. A., \& Terrell, H. K. (2013). No halo effect for sex offenders: an examination of the effects of appearance and gender on the public's perception of sex offenders. Applied Psychology in Criminal Justice,9(2).

Barter, C., \& Renold, E. (1999). The use of vignettes in qualitative research. Social research update, 25(9), 1-6.

Boor, M. (1976). Beautiful is not dangerous, beauty is talent: two failures to replicate the physical attractiveness effects. Catalog of Selected Documents in Psychology, 96, 301302.

Bonta, J., \& Andrews, D. A. (2007). Risk-need-responsivity model for offender assessment and treatment (User Report No. 2007-06). Ottawa, Ontario: Public Safety Canada.

Bottoms, B. L., Peter-Hagene, L. C., Stevenson, M. C., Wiley, T. R. A., Mitchell, T. S., \& Goodman, G. S. (2014). Explaining gender differences in jurors' reactions to child sexual assault cases. Behavioral Sciences \& the Law, 32(6), 789-812.

Briere, J., \& Eliott, D. M. (2003). Prevalence and psychological sequence of self-reported childhood physical and sexual abuse in the general population. Child Abuse and Neglect, $27,1205-1222$.

Burke, D. M., Ames, M. A., Etherington, R., \& Pietsch, J. (1990). Effects of victim's and defendant's physical attractiveness on the perception of responsibility in an ambiguous domestic violence case. Journal of Family Violence, 5(3), 199-207. http://doi.org/10.1007/BF00980815 
Burke, D., Nolan, C., Hayward, W. G., Russell, R., \& Sulikowski, D. (2013). Is there an ownrace preference in attractiveness? Evolutionary Psychology, 11(4), 855-872. doi:10.1177/147470491301100410

Block, T. (2017). The Destructive Spiral. Retrieved from https://www.popsugar.com/love/photogallery/8477494/image/31566490/Destructive-Spiral

Buhrmester, M., Kwang, T., \& Gosling, S. D. (2011). Amazon's Mechanical Turk: A new source of inexpensive, yet high-quality, data? Perspectives On Psychological Science, 6(1), 3-5. doi:10.1177/1745691610393980

Byrne, D., London, O., \& Reeves, K. (1968). The effects of physical attractiveness, sex, and attitude similarity on interpersonal attraction. Journal of personality.

Cairns, A. (2012). Hot For Teacher: Gender Bias in Sentencing of Teachers that have Sex with Their Students. Retrieved from http://campbelllawobserver.com/hot-for-teacher-genderbias-in-sentencing-of-teachers-that-have-sex-with-their-students/

Center for Sex Offender Management (2007). Female sex offenders. Office of Justice Programs, U.S. Department of Justice. Retrieved from http://www.csom.org/pubs/female_sex_offenders_brief.pdf

Collins, G. (2017). 13-Year-Old Student Seduces His Female Teacher On Instagram, But Now She's In Jail. Retrieved from http://thoughtcatalog.com/gray-collins/2017/01/13-year-oldstudent-seduces-his-female-teacher-on-instagram-but-now-shes-in-jail/

Colson, M., Boyer, L., Baumstarck, K., \& Loundou, A. D. (2013). Female sex offenders: A challenge to certain paradigmes. Meta-analysis. Sexologies: European Journal Of Sexology And Sexual Health / Revue Européenne De Sexologie Et De Santé Sexuelle, 22(4), e109-e117. doi:10.1016/j.sexol.2013.05.002 
Cortoni, F., \& Hanson, R. K. (2005). A review of the recidivism rates of adult female sexual offenders (Research Rep. No. R-169). Ottawa, Ontario, Canada: Correctional Service Canada. Retrieved from www.csc-scc.gc.ca/text/rsrch/reports/r169/r169_e.pdf

Cortoni, F., Hanson, R. K., \& Coache, M. E. (2009). Les délinquantes sexuelles: Prévalence et récidive [Female sexual offenders: Prevalence and recidivism]. Revue internationale de criminologie et de police technique et scientifique, LXII, 319-336.

Cross, J. F., \& Cross, J. (1971). Age, sex, race, and the perception of facial beauty. Developmental Psychology, 5(3), 433-439. doi:10.1037/h0031591

Castellow, W. A., Wuensch, K. L., \& Moore, C. H. (1990). Effects of physical attractiveness of the plaintiff and defendant in sexual harassment judgements. Journal of Social Behavior and Personality, 5(6), 547.

Cramer, E. P. (1999). Variables that predict verdicts in domestic violence cases. Journal Of Interpersonal Violence, 14(11), 1137-1150. doi:10.1177/088626099014011002

Darby, B. W., \& Jeffers, D. (1988). The effects of defendant and juror attractiveness on simulated courtroom trial decisions. Social Behavior and Personality, 16(1), 39-50. http://doi.org/10.2224/sbp.1988.16.1.39

Davies, M., \& Rogers, P. (2006). Perceptions of male victims in depicted sexual assaults: A review of the literature. Aggression and Violent Behavior, 11(4), 367-377. doi:10.1016/j.avb.2006.01.002

Deitz, S. R., \& Byrnes, L. E. (1981). Attribution of responsibility for sexual assault: The influence of observer empathy and defendant occupation and attractiveness. The Journal of Psychology: Interdisciplinary and Applied, 108(1), 17-29.

http://doi.org/10.1080/00223980.1981.9915241 
Denov, M. S. (2003). The myth of innocence: Sexual scripts and the recognition of child sexual abuse by female perpetrators. Journal Of Sex Research, 40(3), 303-314. doi:10.1080/00224490309552195

Devine, D. J., \& Caughlin, D. E. (2014). Do they matter? A meta-analytic investigation of individual characteristics and guilt judgments. Psychology, Public Policy, and Law, 20(2), 109-134.

Dion, K., Berscheid, E., \& Walster, E. (1972). What is beautiful is good. Journal of personality and social psychology, 24(3), 285.

Dipboye, R. L., Fromkin, H. L., \& Wiback, K. (1975). Relative importance of applicant sex, attractiveness, and scholastic standing in evaluation of job applicant resumes. Journal of Applied Psychology, 60(1), 39.

Douglas, E. M. \& Finkelhor, D. (2005). Childhood sexual abuse fact sheet. Crimes Against Children Research Center. Retrieved from http://www.unh.edu/ccrc/factsheet/pdf/CSAFS20.pdf

Dvorak, P. (2014). When female teachers prey on male students, it's no teenage fantasy. Retrieved from https://www.washingtonpost.com/local/when-female-teachers-prey-onmale-students-its-no-teenage-fantasy/2014/10/23/335492cc-5ac9-11e4-8264deed989ae9a2_story.html?utm_term=.e714fe3d19c8

Eagly, A. H., Ashmore, R. D., Makhijani, M. G., \& Longo, L. C. (1991). What is beautiful is good, but...: A meta-analytic review of research on the physical attractiveness stereotype. Psychological bulletin, 110(1), 109. 
Efran, M. G. (1974). The effect of physical appearance on the judgment of guilt, interpersonal attraction, and severity of recommended punishment in a simulated jury task. Journal of Research in Personality, 8(1), 45-54.

Erian, M., Lin, C., Patel, N., Neal, A., \& Geiselman, R. E. (1998). Juror verdicts as a function of victim and defendant attractiveness in sexual assault cases. American Journal of Forensic Psychology,16(3), 25-40.

Fallman, J., \& Christianson, S-A. (1999). Kvinnor som do "mts fo $\ddot{r}$ sexualbrott mot barn: Brottens omfattning och karaktär [Women sentenced for sexual abuse of children: The incidence and character of the offences] (Swedish Report Series, No. 103). Stockholm: Department of Psychology, Stockholm University.

Finkelhor, D. (1994). Current information on the scope and nature of child sexual abuse. The Future Of Children, 4(2), 31-53. doi:10.2307/1602522।

Friend, R. M., \& Vinson, M. (1974). Leaning over backwards: Jurors' responses to defendants' attractiveness. Journal of Communication,24(3), 124-129. http://doi.org/10.1111/j.14602466.1974.tb00398.x

Gerdes, E. P., Dammann, E. J., \& Heilig, K. E. (1988). Perceptions of rape victims and assailants: Effects of physical attractiveness, acquaintance, and subject gender. Sex Roles, 19(3-4), 141-153.

Gray, D. B., \& Ashmore, R. D. (1976). Biasing influence of defendants' characteristics on simulated sentences. Psychological Reports, 38(3), 727-738.

Haegerich, T. M., \& Bottoms, B. L. (2000). Empathy and jurors' decisions in patricide trials involving child sexual assault allegations. Law and Human Behavior, 24(4), 421-448. doi:10.1023/A:1005592213294 
Horton, J. J., \& Chilton, L. B. (2010). The labor economics of paid crowdsourcing. Retrieved from http://arxiv.org/pdf/1001.0627.pdf

Izzett, R. R., \& Fishman, L. B. (1976). Defendant sentences as a function of attractiveness and justification for actions. The Journal of Social Psychology, 100(2), 285-290.

Izzett, R. R., \& Leginski, W. (1974). Group discussion and the influence of defendant characteristics in a simulated jury setting. The Journal of Social Psychology, 93(2), 271279. http://doi.org/10.1080/00224545.1974.9923161

Jacobson, M. B. (1981). Effects of victim's and defendant's physical attractiveness on subjects' judgments in a rape case. Sex Roles, 7(3), 247-255.

Jacobson, S. K., \& Berger, C. R. (1974). Communication and justice: Defendant attributes and their effects on the severity of his sentence. Speech Monographs, 41, 282-186.

Jacobson, M. B., \& Popovich, P. M. (1983). Victim Attractiveness and Perceptions of Responsiblity in an Ambiguous Rape Case. Psychology of Women Quarterly, 8(1), 100104.

Jaffe, P., Straatman, A. L., Harris, B., Georges, A., Vink, K., \& Reif, K. (2013). Emerging Trends in Teacher Sexual Misconduct in Ontario 2007-2012. Education Law Journal, 23(1), 19.

Kerr, N. L. (1978). Beautiful and blameless: Effects of victim attractiveness and responsibility on mock jurors' verdicts. Personality and Social Psychology Bulletin, 4(3), 479-482.

Kim, B., Benekos, P. J., \& Merlo, A. V. (2016). Sex offender recidivism revisited: Review of recent meta-analyses on the effects of sex offender treatment. Trauma, Violence, \& Abuse, 17(1), 105-117. doi:10.1177/1524838014566719 
Kinstle, T. L., Hodell, E. C., \& Golding, J. M. (2008). The impact of juror characteristics and victim health status on the perception of elder physical abuse. Journal of Interpersonal Violence, 23(9), 1143-1161.

Kulka, R. A., \& Kessler, J. B. (1978). Is Justice Really Blind?-The Influence of Litigant Physical Attractiveness on Juridical Judgment1. Journal of Applied Social Psychology, 8(4), 366-381.

Grant, M. J., Button, C. M., Hannah, T. E., \& Ross, A. S. (2002). Uncovering the multidimensional nature of stereotype inferences: A within-participants study of gender, age, and physical attractiveness. Current Research In Social Psychology, 8(2), 19-39.

Korthase, K. M., \& Trenholme, I. (1982). Perceived age and perceived physical attractiveness. Perceptual and Motor Skills, 54(3, Pt 2), 1251-1258. doi:10.2466/pms.1982.54.3c.1251

Laerd Statistics. (2017). Three-Way ANOVA. Retrieved from https://statistics.laerd.com/premium/spss/ftwa/three-way-anova-in-spss.php

Landy, D., \& Sigall, H. (1974). Beauty is talent: Task evaluation as a function of the performer's physical attractiveness. Journal of Personality and Social Psychology, 29(3), 299.

Langlois, J. H., Kalakanis, L., Rubenstein, A. J., Larson, A., Hallam, M., \& Smoot, M. (2000). Maxims or myths of beauty? A meta-analytic and theoretical review. Psychological bulletin, 126(3), 390.

Larosa, P. (2014). "48 Hours" investigates sex abuse by women teachers. Retrieved from http://www.cbsnews.com/news/48-hours-investigates-sex-abuse-by-women-teachers/ Leventhal, G., \& Krate, R. (1977). Physical attractiveness and severity of sentencing. Psychological Reports, 40(1), 315-318. 
Matthews, J. K., Mathews, R., \& Speltz, K. (1991). Female sexual offenders: A typology. In M. Q. Patton, M. Q. Patton (Eds.) Family sexual abuse: Frontline research and evaluation (pp. 199-219). Thousand Oaks, CA, US: Sage Publications, Inc. doi:10.4135/9781483325613.n13

Mazzella, R., \& Feingold, A. (1994). The Effects of Physical Attractiveness, Race, Socioeconomic Status, and Gender of Defendants and Victims on Judgments of Mock Jurors: A Meta-Analysis1. Journal of Applied Social Psychology, 24(15), 1315-1338.

McCloskey, K. A., \& Raphael, D. N. (2005). Adult Perpetrator Gender Asymmetries in Child Sexual Assault Victim Selection: Results from the 2000 National Incident-Based Reporting System. Journal Of Child Sexual Abuse: Research, Treatment, \& Program Innovations For Victims, Survivors, \& Offenders, 14(4), 1-24. doi:10.1300/J070v14n04_01

Mezey, G., \& King, M. (1989). The Effects of Sexual Assault on Men: A Survey of 22 Victims. Psychological Medicine, 19, 205-209.

Mills, J., \& Aronson, E. (1965). Opinion change as a function of the communicator's attractiveness and desire to influence. Journal of Personality and Social Psychology, 1(2), 173.

Mitchell, T. L., Haw, R. M., Pfeifer, J. E., \& Meissner, C. A. (2005). Racial Bias in Mock Juror Decision-Making: A Meta-Analytic Review of Defendant Treatment. Law and Human Behavior, 29(6), 621-637. doi:10.1007/s10979-005-8122-9

Nemeth, C., \& Sosis, R. H. (1973). A simulated jury study: Characteristics of the defendant and the jurors. The Journal of Social Psychology, 90(2), 221-229. 
Nisbett, R. E., \& Wilson, T. D. (1977). The halo effect: Evidence for unconscious alteration of judgments. Journal of personality and social psychology, 35(4), 250.

Norman-Eady, S., Reinhart, C., \& Martino, P. (2003, April 14). Statutory Rape Laws by State. Retrieved April 20, 2015, from http://www.cga.ct.gov/2003/olrdata/jud/rpt/2003-r0376.htm

Patrick, S., \& Marsh, R. (2011). Sentencing outcomes of convicted child sex offenders. Journal Of Child Sexual Abuse: Research, Treatment, \& Program Innovations For Victims, Survivors, \& Offenders, 20(1), 94-108. doi:10.1080/10538712.2011.541356

Piehl, J. (1977). Integration of information in the" court:" Influence of physical attractiveness on amount of punishment for a traffic offender. Psychological Reports, 41(2), 551-556.

Pozzulo, J. D., Dempsey, J., Maeder, E., \& Allen, L. (2010). The effects of victim gender, defendant gender, and defendant age on juror decision making. Criminal Justice and Behavior, 37(1), 47-63. doi:10.1177/0093854809344173

Rogers, P., \& Davies, M. (2007). Perceptions of victims and perpetrators in a depicted child sexual abuse case: Gender and age factors. Journal Of Interpersonal Violence, 22(5), 566-584. doi:10.1177/0886260506298827

Haegerich, T. M., \& Bottoms, B. L. (2000). Empathy and jurors' decisions in patricide trials involving child sexual assault allegations. Law and Human Behavior, 24(4), 421-448. doi:10.1023/A:1005592213294

Howell, J. L., Egan, P. M., Giuliano, T. A., \& Ackley, B. D. (2011). The reverse double standard in perceptions of student-teacher sexual relationships: The role of gender, initiation, and power. The Journal Of Social Psychology, 151(2), 180-200.

doi:10.1080/00224540903510837 
Quas, J. A., Bottoms, B. L., Haegerich, T. M., \& Nysse-Carris, K. L. (2002). Effects of victim, defendant and juror gender on decisions in child sexual assault cases. Journal of Applied Social Psychology, 32(10), 1993-2021. doi:10.1111/j.1559-1816.2002.tb02061.x

Rodriguez, S. F., Curry, T. R., \& Lee, G. (2006). Gender differences in criminal sentencing: do effects vary across violent, property and drug offenses? Social Science Quarterly, 87(2), 318339.

Schutte, J. W., \& Hosch, H. M. (1997). Gender differences in sexual assault verdicts: A metaanalysis. Journal Of Social Behavior \& Personality, 12(3), 759-772.

Shakeshaft, C. (2004). Educator Sexual Misconduct: A Synthesis of Existing Literature PPSS 2004-09. US Department of Education.

Shechory-Bitton, M., \& Zvi, L. (2015). The effect of offender's attractiveness and subject's gender on judgments in swindling. Psychiatry, Psychology and Law, 22(4), 559-570. http://doi.org/10.1080/13218719.2014.960037

Simcha (2008). The Top 5 Songs About Sexy Teachers. Retrieved from http://www.thefrisky.com/2008-09-10/the-top-5-songs-about-sexy-teachers/

Sigal, J., Braden, J., \& Aylward, G. (1978). The effect of attractiveness of defendant, number of witnesses, and personal motivation of defendant on jury decision making behavior. Psychology: A Journal of Human Behavior, 15(3), 4-10.

Sigall, H., \& Ostrove, N. (1975). Beautiful but dangerous: Effects of offender attractiveness and nature of the crime on juridic judgment. Journal of Personality and Social Psychology, 31(3), 410.

Simons, D. A. (n.d.). Chapter 3: Sex Offender Typologies. Retrieved from https://www.smart.gov/SOMAPI/sec1/ch3_typology.html 
Smith, E. D., \& Hed, A. (1979). Effects of offenders' age and attractiveness on sentencing on mock juries. Psychological Reports, 44(3), 691-694.

Solomon, M. R., \& Schopler, J. (1978). The relationship of physical attractiveness and punitiveness: Is the linearity assumption out of line? Personality and Social Psychology Bulletin, 4(3), 483-486. doi:10.1177/014616727800400326

Stennis Jr, J. (2006). Equal Protection Dilemma: Why Male Adolescent Students Need Federal Protection From Adult Female Teachers Who Prey on Them. JL \& Educ., 35, 395.

Stewart, J. E. (1980). Defendant's attractiveness as a factor in the outcome of criminal trials: An observational study. Journal of Applied Social Psychology, 10(4), 348-361. http://doi.org/10.1111/j.1559-1816.1980.tb00715.x

Stewart, J. E. (1985). Appearance and punishment: The attraction-leniency effect in the courtroom. The Journal of social psychology, 125(3), 373-378.

Stroebe, W., Insko, C. A., Thompson, V. D., \& Layton, B. D. (1971). Effects of physical attractiveness, attitude similarity, and sex on various aspects of interpersonal attraction. Journal of Personality and Social Psychology, 18(1), 79.

Thorndike, E. (1920). A constant error in psychological ratings. Journal Of Applied Psychology, 4(1), 25-29. doi:10.1037/h0071663

Thornton, B. (1977). Effect of rape victim's attractiveness in a jury simulation. Personality and Social Psychology Bulletin, 3(4), 666-669.

Thomas, S. (1999). Dirty secrets chart: Pennsylvania teacher discipline cases, 1990-1999. Post Gazette. Retrieved November 2, 1999, from http://www.postgazette.com/regionstate/19991102dschart3.asp 
The National Center for Victims of Crime (n.d.). Statistics on Perpetrators of Child Sexual Abuse. Retrieved from https://victimsofcrime.org/media/reporting-on-child-sexualabuse/statistics-on-perpetrators-of-csa

Walker, J., Archer, J., \& Davies, M. (2005). Effects of male rape on psychological functioning. British Journal of Clinical Psychology, 44, 445-451.

Wilson, D. W., \& Donnerstein, E. (1977). Guilty or Not Guilty? A Look at the "Simulated" Jury Paradigm1. Journal of Applied Social Psychology, 7(2), 175-190.

West, S. G., Friedman, S. H., \& Kim, K. D. (2011). Women accused of sex offenses: A genderbased comparison. Behavioral Sciences \& The Law, 29(5), 728-740. doi:10.1002/bsl.1007

Wuensch, K. L., Castellow, W. A., \& Moore, C. H. (1991). Effects of defendant attractiveness and type of crime on juridic judgement. Journal of Social Behavior and Personality, 6(4), 713.

Wuensch, K. L., Chia, R. C., Castellow, W. A., Chuang, C. J., \& Cheng, B. S. (1993). Effects of Physical Attractiveness, Sex, and Type of Crime on Mock Juror Decisions A Replication with Chinese Students. Journal of Cross-Cultural Psychology, 24(4), 414-427. 